\title{
Research progress in metal-free carbon-based catalysts
}

\author{
SUN Xiaoyan ${ }^{\mathrm{a}}$, WANG Rui a,b, SU Dangsheng a,* \\ a Shenyang National Laboratory for Materials Science, Institute of Metal Research, Chinese Academy of Sciences, Shenyang 110016, Liaoning, China \\ ${ }^{\mathrm{b}}$ National Institute of Clean-and-Low-Carbon Energy, Beijing 102211, China
}

\section{A R T I C L E I N F O}

\section{Article history:}

Received 10 November 2012

Accepted 6 January 2013

Published 20 March 2013

\section{Keywords:}

Nanocarbon

Metal-free

Heterogeneous catalysis

\begin{abstract}
A B S T R A C T
Metal-free carbon-based catalysts are one of the most active research directions in nanomaterials and catalysis. The advantages that nanocarbon catalysts have over metal catalysts include high efficiency, environmental compatibility, low energy consumption, and corrosion resistance. Nanocarbon can efficiently catalyze alkane conversion, chemical synthesis, energy catalysis and other heterogeneous catalytic processes. This review highlights recent progress in the development of metal-free carbon-based catalysts, including understanding their surface properties, catalytic performance and reaction mechanism and macroscopic architecture. The state-of-the-art and future challenges of metal-free heterogeneous catalysis are also discussed.
\end{abstract}

(C) 2013, Dalian Institute of Chemical Physics, Chinese Academy of Sciences. Published by Elsevier B.V. All rights reserved.

\section{Introduction}

Metal-free catalysts are newly emerging green catalytic materials that have attracted much attention in recent years for their advantanges of high efficiency, environment friendliness and economy in many industrial catalytic processes. There are a variety of organic metal-free catalysts, such as small organic molecules containing $\mathrm{N}, \mathrm{P}$ electron-rich center, dendrimers, ionic liquids, etc., which have been widely used in various homogeneous organic reactions for rearrangement reactions, cycloaddition, condensation, alkylation and carbonylation [1-3].

An important type of inorganic metal-free catalysts developed in recent years are nanocarbon materials that have demonstrated superior catalytic performance to traditional metal catalysts in many fields, including hydrocarbon conversion, fine chemicals production, fuel cells, and solar energy $[4,5]$. Metal-free carbon-based catalysis has become one of the most promising research directions in nanomaterials and ca- talysis. The carbon material itself is used as the catalyst and no metal is loaded or added, so the active sites for the reaction are the defective structure or functional groups on the carbon surface. Compared with a metal-based catalyst, a nanocarbon catalyst has the advantages of low cost, no heavy metal pollution and environmental friendliness, while showing high selectivity and long term stability under mild conditions in many catalytic processes. This review focuses on the key issues of their catalytic properties in heterogeneous catalytic system, the reaction mechanism and macroscopic architecture of metal-free carbon-based catalysts.

\section{Structure and surface chemistry of nanocarbon materials}

Many carbon materials used in catalysis have the graphitic structure. These marterials include conventional activated carbon, carbon black and graphite, and also the new nanomaterials of fullerenes, nanotubes and nanofibers,

\footnotetext{
* Corresponding author. Tel: +86-24-83970029; Fax: +86-24-83970019; E-mail: dssu@imr.ac.cn This work was supported by the National Natural Science Foundation of China (21133010, 21103203, and 50921004), the National Basic Research Program of China (973 Program, 2011CBA00504), and the Thousand Talents Program of the Central Organization Department. DOI: 10.1016/S1872-2067(11)60515-9 | http://www.sciencedirect.com/science/journal/18722067 | Chin. J. Catal., Vol. 34, No. 3, March 2013
} 
graphene and mesoporous carbon.

Nanocarbon materials are prepared by severe chemical processes such as laser arc discharge, ablation and chemical vapor deposition, and thus a large amount of structural defects are introduced into the carbon surface. The terminating surface of a curved graphitic structure requires new foreign atoms to saturate the dangling bonds at the defects and edges. After chemical post-treatment, these sites can be modified with heteroatoms to provide strong chemical reactivity for acid-base and redox chemistry. Oxygen and nitrogen atoms are the most frequently incorporated atoms. Figure 1 summarizes the different oxygen and nitrogen functional groups found on carbon surfaces [4]. Oxygenated functional groups have been the most extensively studied because they are formed spontaneously by the exposure of the carbon material to the atmosphere. Acidic oxygen groups include carboxylic acids, anhydrides, lactones and phenols. Carbonyls and ether oxygen species, such as quinones, pyrones, and benzopyrans are generally alkaline or neutral oxygen functional groups.

\section{Catalytic performance of nanocarbon materials}

The excellent catalytic performance of nanocarbon materials is due to their unique properties. First, most nanocarbons with a nanographite structure possess good electrical conductivity and ability to store/release electrons, which facilitates the rate of electron transfer in the critical step of the catalytic reaction and increases the overall reaction rate. Second, nanocarbon materials have very high specific surface areas and mesopore volumes, and have more surface active sites than conventional materials, thus improving the catalytic performance by the faster diffusion of reactant molecules in the mesopores. Finally, the higher concentration of surface defects on the nanocarbon materials can be functionalized with more oxygen and nitrogen heteroatoms. Table 1 lists some common reactions that are catalyzed by nanocarbon materials and the required surface functional groups or active sites [5].

\subsection{Gas phase reactions}

In the past few years, most studies of gas phase reactions catalyzed by nanocarbons were focused on the oxidative dehydrogenation system. In 2001, Robert Schlögl's research group carried out the oxidative dehydrogenation (ODH) of ethylben-

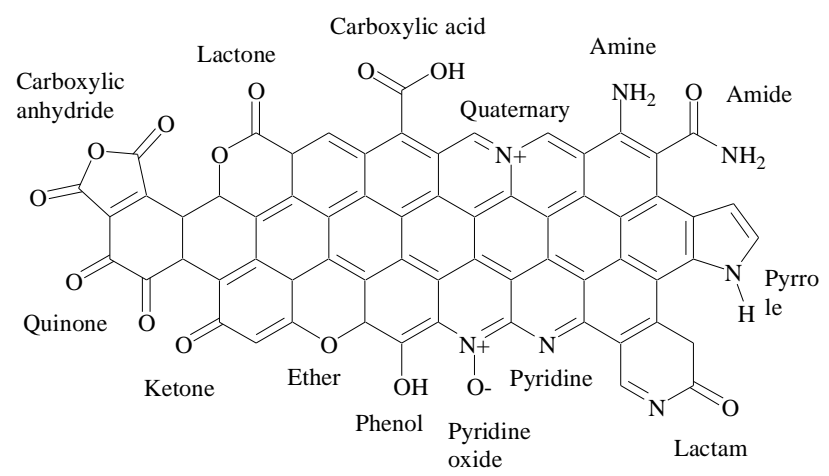

Fig. 1. Nitrogen and oxygen surface groups on nanocarbon [4].
Table 1

Overview of reactions catalyzed by carbon, and the surface chemistry and active sites [5].

\begin{tabular}{lc}
\hline Reactions & Surface chemistry/active sites \\
\hline $\begin{array}{l}\text { Gas phase } \\
\text { Oxidative dehydrogenation }\end{array}$ & - \\
$\begin{array}{l}\text { Dehydration of alcohols } \\
\text { Dehydrogenation of alcohols } \\
\mathrm{NO}_{x} \text { reduction (SCR with } \mathrm{NH}_{3} \text { ) }\end{array}$ & $\begin{array}{c}\text { quinones } \\
\text { carboxylic acids } \\
\text { lewis acids and basic sites } \\
\text { acidic surface oxides } \\
\text { (carboxylic and lactone) + } \\
\text { basic sites (carbonyls or N5, N6) }\end{array}$ \\
$\mathrm{NO}_{2}$ oxidation & basic sites \\
$\mathrm{H}_{2} \mathrm{~S}$ oxidation & basic sites, pyridinic-N6 \\
Dehydrohalogenation & basic sites \\
Liquid phase & pyridinic nitrogen sites \\
Hydrogen peroxide reactions & basic sites \\
Catalytic ozonation & basic sites \\
Catalytic wet air oxidation & basic sites
\end{tabular}

zene using carbon nanofibers as the catalyst [6,7] and found that the carbon nanofibers showed a higher catalytic activity than highly dispersed graphite at the reaction temperature of $547{ }^{\circ} \mathrm{C}$, and also had a far superior stability to traditional amorphous carbon black. A series of studies subsequently demonstrated that many nanostructured carbons can efficiently catalyze the ODH reaction of ethylbenzene to styrene (Fig. 2), and that these catalysts exhibited comparable or even better activities than the traditional iron oxide catalysts [8-13]. This is because the defects of the carbon surface can anchor functional groups as the active sites, while the graphitic structure can tightly hold the active sites to give excellent thermal stability even under an oxidative atmosphere [14]. In 2008, Su et al. [15] first reported that the oxidative dehydrogenation of butane to butene and butadiene can be catalyzed by carbon nanotubes. When the carbon nanotubes were additionally modified by passivation of the defects with phosphorus oxide, the resulting CNTs gave improved catalytic activity, while the reaction temperature was further decreased by $100-200{ }^{\circ} \mathrm{C}$ below the industrial catalytic process. The surface oxygen species on the surface of nanocarbon materials can be classified into electrophilic and nucleophilic types. Nucleophilic oxygen species preferentially react with electron-poor saturated bonds in al-

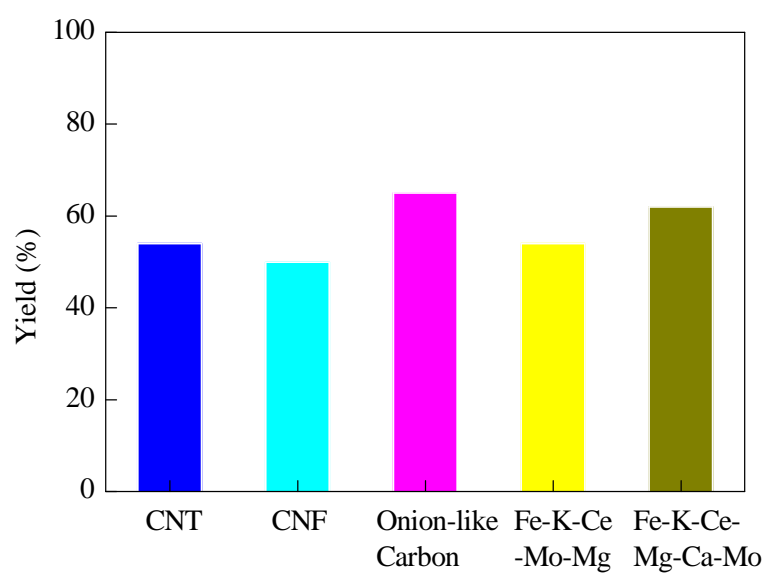

Fig. 2. Styrene yield over nanocarbon materials and metal catalysts in oxidative dehydrogenation [13]. 
kanes, leading to the ODH reaction that formed alkenes. Electrophilic oxygen species are electron-deficient and will attack the electron-rich $\mathrm{C}=\mathrm{C}$ bonds in alkenes, leading to the further oxidation of the reactants and dehydrogenation products and subsequent combustion, thus resulting in a decrease in selectivity. It has also been reported that the doping of a trace amount of boron oxide into the graphite lattice structure can modify the distribution of the electron cloud and inhibit the activity of the electrophilic oxygen species, leading to improved selectivity to alkene target products [16].

The nature of the active sites of carbon catalytic materials has become one of hottest topics in recent studies. Pereira et al. [17] found a linear correlation between activity in the oxidative dehydrogenation of ethylbenzene and concentration of carbonyl/quinone surface groups. Kinetic studies indicated that the oxidation dehydrogenation of ethylbenzene over activated carbon followed the Mars-van-Kreverlan mechanism, in which the catalytic activity is related with the redox ability of the surface oxygen species. Dangsheng Su's research group [18-20] made a breakthrough on the reaction mechanism and the identification of active species by studying the reaction kinetics of ethylbenzene and butane dehydrogenation in combination with in situ X-ray photoelectron spectroscopy for the first time. Similar to most metal-based catalysts, the reaction catalyzed by carbon materials is based on a dual site Langmuir-Hinshelwood mechanism, and carbonyl/quinone groups on the surface are the active sites $[19,20]$. It was reported that diketone-like carbonyl groups can abstract hydrogen atoms from the $\mathrm{C}-\mathrm{H}$ bonds of alkanes to produce the corresponding alkenes. Reaction of gas phase oxygen with the abstracted hydrogen regenerates the active sites, with the formation of water as the product, as shown schematically in Fig. 3. Besides the oxidative dehydrogenation of ethylbenzene, a similar reaction mechanism has been also proposed for other oxidative dehydrogenation processes, such as cyclohexanol to cyclohexanone on nanocarbon fibers [21], 1-butene to butadiene [22], propane to propene [16], and ethane to ethylene [23].

Surface defects on carbon materials play an important role in the catalytic nature of the nanocarbons. Muradov et al. [24] found that carbon materials can catalyze methane decomposition into hydrogen at high temperature. More than 30 types of carbon materials were demonstrated to show good catalytic activities, including activated carbon, carbon black, graphite, $\mathrm{C}_{60}$, CNT and diamond, among which carbon black showed the best specific activity. A clear correlation was observed between the catalytic activity for methane decomposition and the degree

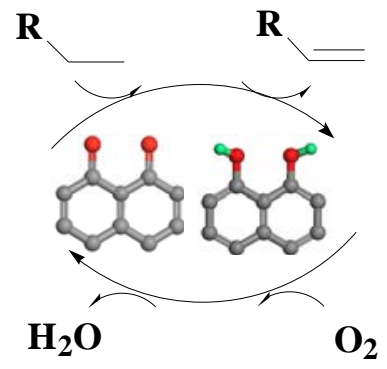

Fig. 3. Oxidative dehydrogenation of alkanes over nanocarbon catalysts. of structural order. With decreasing crystallite size of the carbon materials, a more disordered structure gave a significant increase in the catalytic activity [25]. This observation implied that the active sites for the carbon-catalyzed decomposition of methane are dependent on the defects on the surface. This conclusion was further confirmed by first principle calculations by Huang et al. [26] and acetylene chemisorption by Lee et al. [27]. Liang et al. [28] found that for oxidative dehydrogenation over isobutene fullerene-like graphitic carbons, no clear correlation was observed between the catalytic activity and the amount of surface functional groups, while the catalytic activity was related to the openness of the fullerene-like cavities. So far, due to a lack of effective approaches to directly identify and quantify the types and numbers of surface defects, the mechanism and the nature of active sites for most carbon-catalyzed gas phase reactions still remain controversial.

Recent development of carbon nanomaterials in some new reactions offer new directions for expanding the applications of metal-free carbon-based catalysts. Our recent work [29] achieved the steam- and coke-free dehydrogenation of ethylbenzene by using nanodiamond as the catalyst (Fig. 4). With the absence of gaseous oxygen and steam, the nanodiamond displayed three times the activity of the commercial iron oxide catalyst at a lower temperature. After a long term of reaction, the surface of the nanodiamond was free of deposited
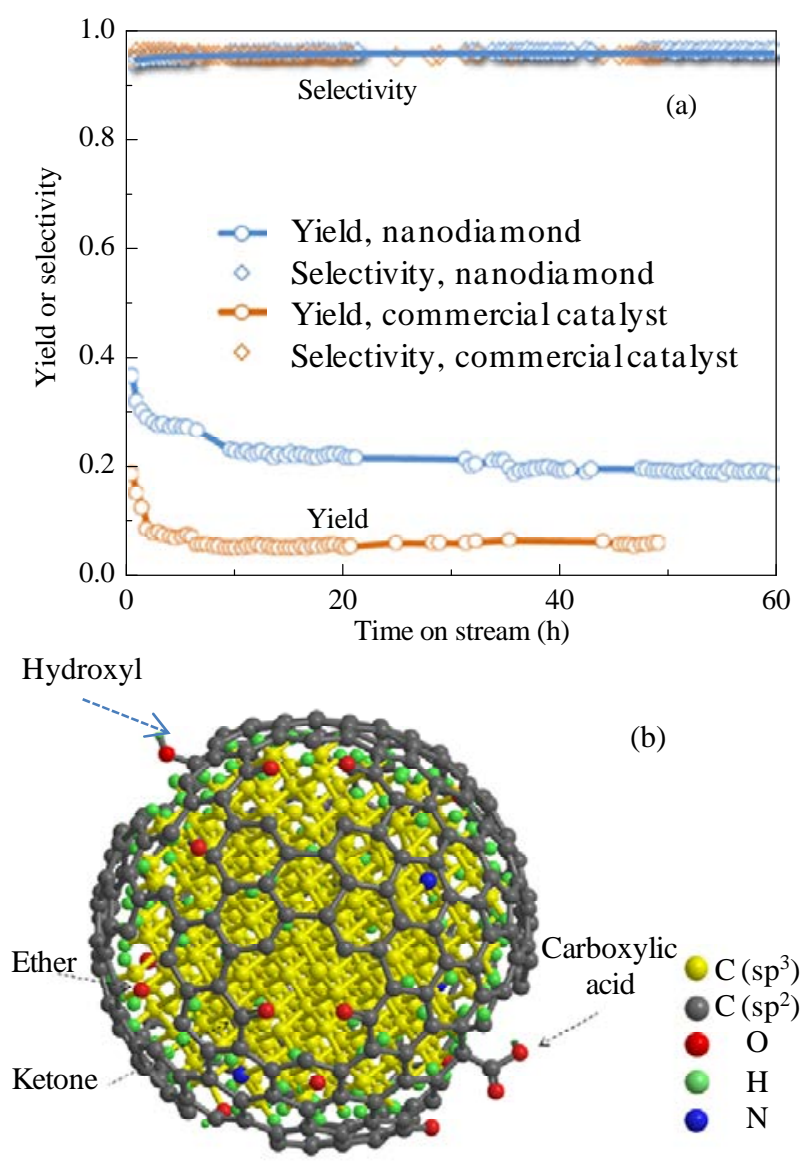

Fig. 4. Ethylbenzene dehydrogenation activity over nanodiamond compared to a commercial $\mathrm{Fe}_{2} \mathrm{O}_{3}$ catalyst. Reaction conditions: $0.05 \mathrm{~g}$, $550{ }^{\circ} \mathrm{C}, 2.8 \% \mathrm{~EB}$ in helium, $10 \mathrm{ml} / \mathrm{min}$ [29] (a) and the structure of nanodiamond (b). 
carbon. This new strategy has a promising future in the ethylbenzene dehydrogenation industry. It was found that the nanodiamond nanoparticle is not in a complete $s p^{3}$ hybridized state, and the carbon atoms on the surface were affected by the surface curvature and caused graphitization, resulting in a diamond-graphene core-shell structure. The surface graphene layer is highly defective and rich in oxygen-containing groups, which gave the outstanding catalytic performance of nanodiamond. Subsequently, nanodiamond was used to catalyze the oxidative dehydrogenation of $n$-butane [30]. The surface of the nanoparticle tended to be transformed into a diamond core with three to ten layers of fullerene shells during reaction. During this phase transformation from the $s p^{3}$ to the $s p^{2}$ hybridized state, quinoidic carbonyl groups were selectively generated and the formation of electrophilic oxygen species was effectively suppressed, which greatly enhanced product selectivity to the desired butenes. Recently, Frank et al. [31] investigated the catalytic performance of a variety of carbon materials for the selective oxidation of acrolein. The results showed that carbon materials with the structure of a curved graphene sheet, such as carbon nanotubes and onion-like carbon, gave good catalytic performance, while nanodiamond with a mainly $s p^{3}$-hybridized state had a relatively low selectivity for the formation of acrylic acid. The reaction mechanism for selective $\mathrm{C}_{3} \mathrm{H}_{4} \mathrm{O}$ oxidation was proposed as dissociative adsorption of oxygen molecule on the (0001) basal plane to form mobile epoxy groups, which migrated to the prismatic edge sites. The adsorption of $\mathrm{C}_{3} \mathrm{H}_{4} \mathrm{O}$ at the nucleophilic oxygen sites, i.e., the ketones/quinones, initiated its oxygenation by epoxy oxygen atoms to form acrylic acid (Fig. 5).

\subsection{Liquid phase reactions}

Besides gas phase dehydrogenation reactions, the applications of nanocarbons in liquid phase reactions have also attracted increasing interest. Besso et al. [32] reported that a carbon material derived from an activation treatment of phenolic resin can efficiently catalyze the liquid phase oxidation of cyclohexanone with a high selectivity to adipic acid of 33\%. No obvious linear correlation was observed between the amount of oxygen functional groups and catalytic activity of cyclohexanone oxidation, indicating that the liquid phase oxidation pro-

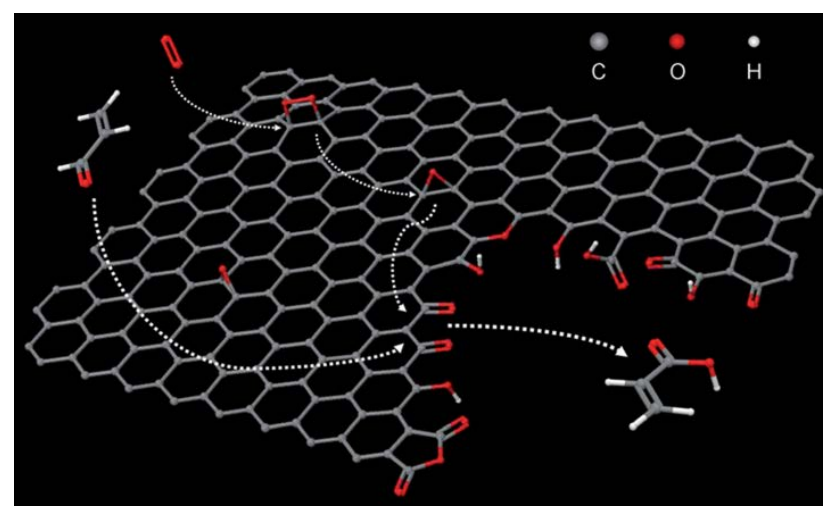

Fig. 5. Reaction pathway for the oxidation of $\mathrm{C}_{3} \mathrm{H}_{4} \mathrm{O}$ at a graphitic carbon surface [31]. cess was much more complicated than the gas phase oxidative dehydrogenation. Kuang et al. [33] found that the nanocarbon material can be directly involved in the reaction cycle of the catalytic oxidation of alcohols. The reaction of oxygen molecules with alcohol readily occurs over nanocarbons in nitric acid under mild conditions. In addition, carbon nanotubes can catalyze the reaction of $\mathrm{H}_{2} \mathrm{O}_{2}$ hydroxylation of benzene, toluene, chlorobenzene and nitrobenzene [34], in which the oxygen activation ability had been related to the surface curvature of the carbon nanotubes. A correlation between curvature and activity has also been reported in the studies of oxidative dehydrogenation of 9,10-dihydroanthracene using multi-walled carbon nanotubes. The curvature of the nanotubes favor a strong Van der Walls interaction with the roof-shaped 9,10-dihydroanthracene and consequently helped the catalytic reaction [35]. Feng Peng's research group has studied catalytic esterification using acid-modified catalysts since 2004 [36-38]. Recently, they found [39] that the catalytic property of carbon nanotubes in the aerobic oxidation of cyclohexane to cyclohexanol was inversely proportional to the amount of surface oxygen functionalities. This effect was probably due to the localization of electrons as a result of the introduction of functional groups and defects, while CNTs with better long range order and electron delocalization were preferred for the reaction. In addition, carbon materials can be used as the catalyst for wet air oxidation of phenol-containing wastewater. This process is an electrophilic reaction involving a chain mechanism of the $\mathrm{OH} \bullet$ radical. However, the active sites and the factors influencing the catalytic properties of carbon materials have not yet been determined. Yang et al. [40] suggested that carboxyl groups played the role of active sites for phenol oxidation reaction catalyzed by carbon nanotubes. Aguilar et al. [41] proposed that the catalytic activity for the oxidation elimination reaction of nitrogen-containing pollutants with carbon materials was independent of the surface acidic groups, while alkaline ketones/benzoquinone groups as active sites were responsible for the reaction. Ma et al. [42] reported that the hydrogenation of nitrobenzene was efficiently catalyzed by reduced graphene oxide (RGO) at room temperature. The zigzag edges of RGO facilitate the activation of a reactant molecule.

The specific acidic or basic surface properties that originate from the functionalizations on carbon surface suggest that these should also be considered solid acid or base catalysts. Wang et al. [43] synthesized a porous sulfonated carbon material by using diazo acid. The catalyst showed good catalytic performance in the reactions of esterification and condensation. Amino-functionalization can provide specific basicity for carbon materials. It has been reported that amino-functionalized carbon nanotubes as a solid base catalyst can efficiently catalyze the transesterification reaction of triglycerides and methanol [44], and furthermore the catalyst is easy to recycle. Yuan et al. $[45,46]$ studied the transesterification of phenol and dimethyl oxalate to synthesize diphenyl oxalate and oxalic acid benzyl ester, and observed that mesoporous carbon materials modified by ethylenediamine exhibited a superior catalytic activity to the supported metal oxide catalyst. Moreover, the modified catalyst can be reused with almost unchanged 
activity. Kan-nari et al. [47] reported that amino-functionalized activated carbon displayed a high catalytic activity in knoevenagel condensation and transesterification reactions.

Graphene oxides (GO) have good potential in organic reactions due to their unique physical and chemical features (highly acidic and strongly oxidative abilities), and have been used in the oxidation of sulphide [48], olefins and various hydrocarbons [49], Friedel-Crafts reaction [50], Aza-Michael additions [51], condensation [52] and ring opening polymerization [53]. Bielawski et al. [54] investigated the catalytic activity of various synthesis reactions under mild conditions in the liquid phase. In 2010, they first reported [55] the remarkable ability of GO to catalyze the oxidation of a variety of alcohols to ketones/aldehydes, alkenes to diones, and alkynes to the corresponding hydrates. The main drawback was that the efficiency of GO was low, and a high loading (60 wt\%-400 wt\%) was required for typical oxidative reactions. Loh et al [56] reported that a sequential base and acid treatment can enhance the activity of GO by creating defects and they reduced the catalyst loading to as low as 5\% and still achieved yields up to $98 \%$ for the oxidative coupling of amines to imines under mild conditions.

Mesoporous graphitic carbon nitrides (denoted as mpg- $\mathrm{C}_{3} \mathrm{~N}_{4}$ ) [57-59] is a novel graphite-like material that has also exhibited excellent catalytic activities in some liquid phase organic reactions, such as Friedel-Crafts acylation reactions and cyclization of cyano and alkynyl compounds. The reactant molecules can be activated by hydrogen bonding to amino groups or electron transfer with mpg- $\mathrm{C}_{3} \mathrm{~N}_{4}$. Alkali-treated carbon nitrides can be used as a solid base catalyst to catalyze Knoevenagel condensation and transesterification reactions [60]. A series of studies by Wang et al. [61] demonstrated that doped mpg- $\mathrm{C}_{3} \mathrm{~N}_{4}$ had excellent catalytic performance in liquid phase oxidation reactions. By using clean hydrogen peroxide or oxygen as the oxidizing agent, the reactions could overcome a serious of pollution problems present in the current conventional oxidation process, while also possessing the advantages of high selectivity, easy separation from the products and recycling. Boron- and fluorine-containing mesoporous carbon nitride polymers exhibited good catalytic performance for the selective oxidation of cyclohexane to cyclohexanone [62]. With a few percent boron and fluorine, the selectivity towards cyclohexanone was as high as $100 \%$ (conversion of $5.3 \%$ ). Boron-doped $\mathrm{C}_{3} \mathrm{~N}_{4}$ can efficiently catalyze the liquid phase oxidation of toluene/ethylbenzene to benzaldehyde/acetophenone with high selectivity (nearly $100 \%$ ), as well as many other aromatic hydrocarbon oxidation reactions [63].

\subsection{Electrocatalytic oxygen reduction reactions}

Highly active catalysts for the oxygen reduction reactions (ORR) have long been regarded as a key to the performance of fuel cells. Although Pt-based catalysts are regarded as the best cathode materials for fuel cells, their large scale commercialization is impeded by poor durability, CO deactivation, high cost and limited supply. To reduce or replace the Pt-based electrodes in fuel cells, extensive efforts have been devoted to de- velop some alternative ORR catalysts, such as transition metal chalcogenides, enzyme electrocatalytic catalysts and nitrogen enriched carbon materials. In situ nitrogen-doped carbon nanotubes and mesoporous graphite arrays have been considered potential metal-free catalysts due to their excellent electrocatalytic activity, low cost, long durability and environmental friendliness $[13,64,65]$.

The nitrogen atom can be bonded to the carbon atom through five covalent electrons because of their similar radius, and hence by controlling the amount of nitrogen incorporated or the doping method, the physical and chemical properties of the carbon material can be altered, improving the electronic properties, conductivity, basicity, oxidation stability and catalytic performance $[64,66]$. Nitrogen-doping into carbon nanostructure materials can be performed in two ways. One is by in situ doping during synthesis by using nitrogen containing precursors, which yield a homogeneous incorporation of nitrogen into the entire carbon material. The other way is by post-synthesis treatment of the carbon materials with nitrogen-containing precursors (e.g., $\mathrm{NH}_{3}$ ), which leads to surface functionalization only without changing the bulk properties. Nitrogen-doped carbons are generally synthesized by the pyrolysis of transition metal macrocyclic compounds [67] or the reaction of metal salts with nitrogen-containing precursor [68]. Because the complete removal of metal contaminants is so difficult even by an extreme purification treatment, the catalytic mechanism of ORR still remains controversial regarding the role of the metal present in a very small amount. In 2006, a nitrogen-doped carbon catalyst was prepared by the decomposition of acetonitrile vapor on pure alumina which contained less than $0.0001 \%$ metal contamination [69]. Compared with the iron supported on alumina catalyst, the nitrogen-doped carbon supported on alumina with no metal impurity was also quite active for ORR, demonstrating that the metal was not required for ORR activity. Liu et al. [70] reported the fabrication of novel nitrogen-doped ordered mesoporous graphitic arrays (NOMGAs) on the basis of a metal-free nanocasting technology. This material exhibited a much higher electrocatalytic activity and stability than the commercial Pt-C catalyst for the ORR reaction. The superior performance was attributed to the incorporation of nitrogen atoms into the catalyst. Recently, Gong et al. [65] found that vertically aligned nitrogen-containing CNTs (VA-NCNTs) act as extremely effective metal-free ORR electrocatalysts (Fig. 6). The metal-free VA-NCNTs were shown to catalyze a four-electron ORR process free from $\mathrm{CO}$ poisoning with a much higher electrocatalytic activity and better long term operation stability than commercial Pt-based electrodes in alkaline electrolytes. They attributed the improved catalytic performance to the electron-accepting ability of nitrogen atoms, which increased the net positive charge density on adjacent carbon atoms in the conjugated nanotube carbon plane. This result has also provided new experimental evidence as well as a promising prospect for the development of alternative metal-free electrocatalysts to platinum.

At present, at least three different forms of the nitrogen atom have been found on the nanocarbon surface, including pyr- 

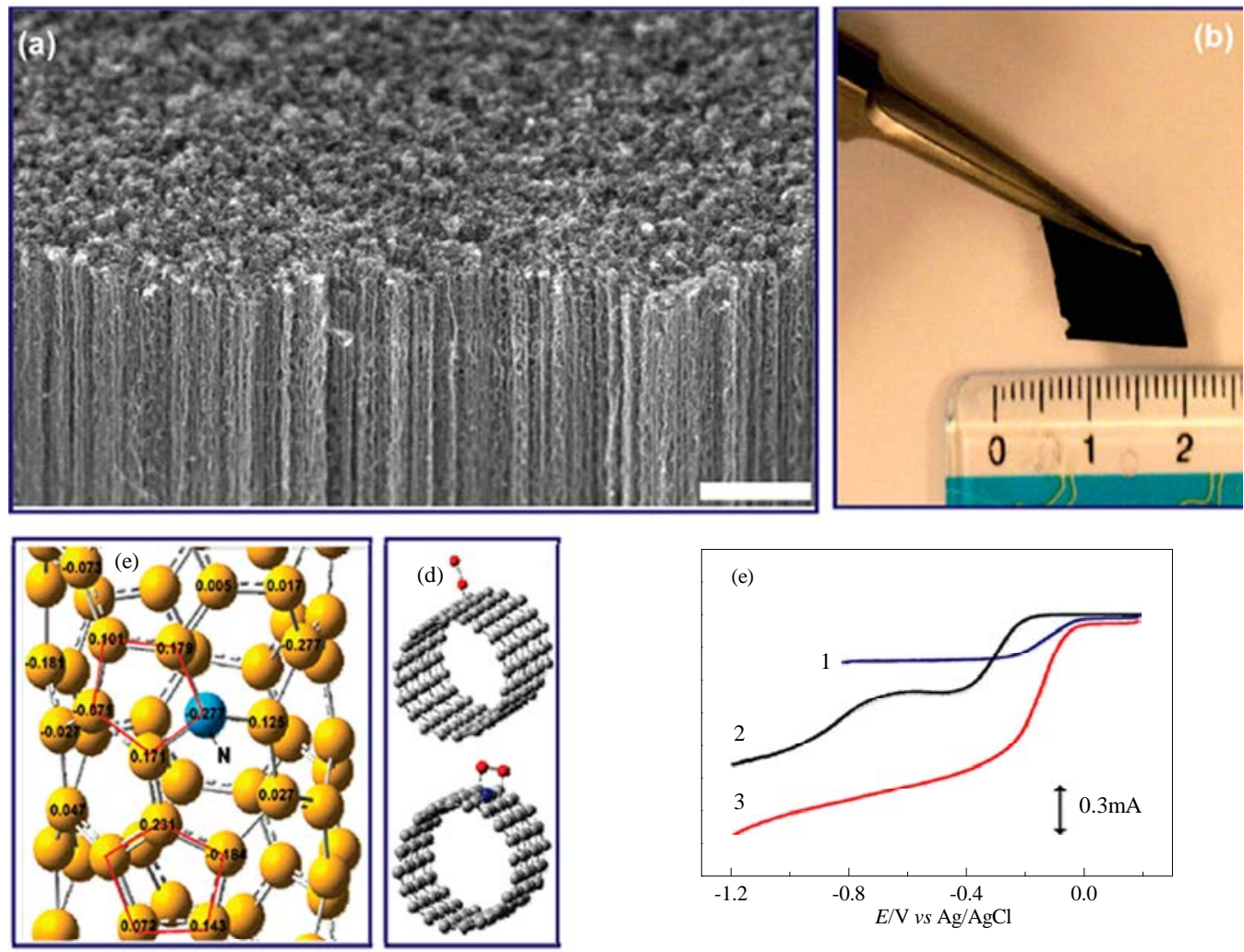

Fig. 6. SEM image of the as-synthesized VA-NCNTs on a quartz substrate (a), digital photograph of the VA-NCNT array after transfer onto a PS-nonaligned CNT conductive nano-composite film (b), calculated charge density distribution for the NCNTs (c), schematic representations of possible adsorption modes of an oxygen molecule at the CCNTs (top) (d) and NCNTs (bottom) Rotating ring-disk electrode (RRDE) voltammograms for oxygen reduction in air saturated $0.1 \mathrm{~mol} / \mathrm{L} \mathrm{KOH}$ at Pt-C (curve 1), VA-CCNT(curve 2), and VA-NCNT(curve 3) electrodes (e) [65].

rolic, pyridinic, and graphitic nitrogen (Fig. 7) [71]. The exact catalytic role for each of the nitrogen forms in nanocarbon ORR catalysts is still a matter of discussion. It is generally believed that the pyridinic nitrogen atoms on the edges of graphitic planes are active sites in the catalytic process [72-74]. However, recent studies have suggested that the graphitic nitrogen atoms are very important for catalyzing ORR $[70,75]$. In addition, it was also reported recently that the nitrogen atoms increase the interaction with the oxygen atoms through their electron donating function. The anion radical, $\mathrm{O}_{2}{ }^{-}$, formed at the surface, is more effective for $N$-containing carbons $[76,77]$.

One atom thick graphene sheets with a two dimensional (2D) planar geometry configuration are superior to CNTs, and can further facilitate electron transport, and hence it can be used as a more effective electrode material. Recently, $N$-doped graphene have been shown to have excellent ORR performance similar to that of $\mathrm{N}$-doped carbon nanotubes with the same nitrogen content [78]. Mullen et al. [79] recently reported the synthesis of graphene-based carbon nitride nanosheets (G-CN Nanosheets). The resulting G-CN nanosheets not only possessed the advantages of a high nitrogen content, thin thicknesses and high surface areas, but also showed excellent electrocatalytic performance for ORR, including high electrocatalytic activity, long term stability, and high selectivity. All these performance were superior to those observed for $\mathrm{CN}$ sheets without graphene and commercial Pt-C catalysts. The application of other carbon materials in electrocatalysis has also attracted attention. Ozaki et al. [80] reported excellent ORR activity in $0.5 \mathrm{~mol} / \mathrm{L}_{2} \mathrm{SO}_{4}$ with shell-like nanocarbons produced by the carbonization of furan resin in the presence of acetylacetonates and metal phthalocyanines.

\subsection{Photocatalytic reactions}

The direct conversion of solar energy into chemical energy is the most promising and effective route to be environment-friendly and relieve the energy crisis. The route can be

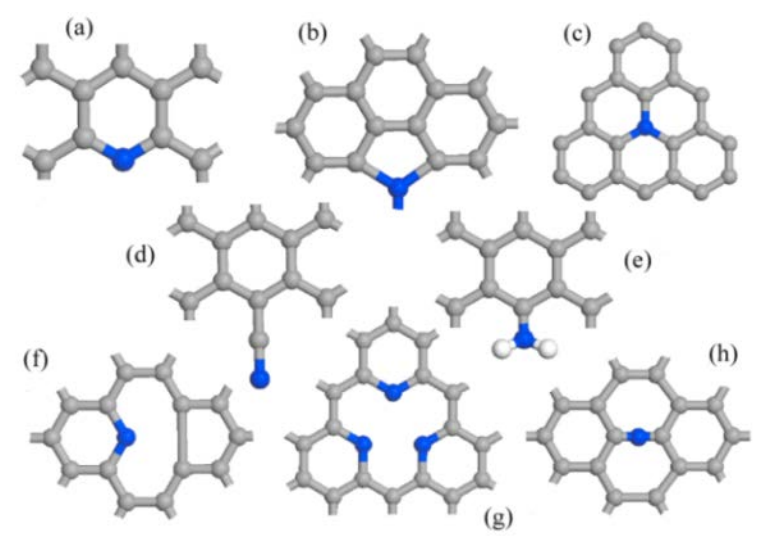

Fig. 7. Bonding configurations for $\mathrm{N}$ in CNTs. (a) pyridine-like $\mathrm{N}$; (b) pyrrole-type $\mathrm{N}$; (c) graphite-like $\mathrm{N}$; (d) Nitrile-C $\equiv \mathrm{N}$; (e) $-\mathrm{NH}_{2}$; (f) pyridinic N-vacancy complex; (g) pyridinic $\mathrm{N}_{3}$-vacancy; (h) interstitial $\mathrm{N}$ [71]. 


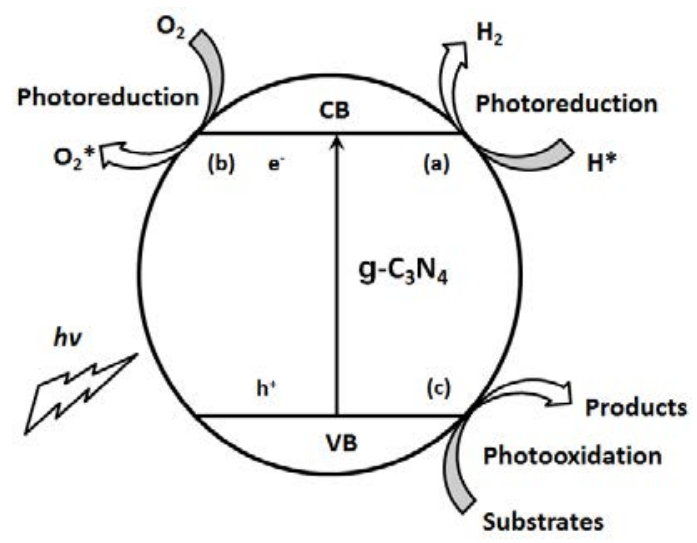

Fig. 8. Strategies for visible light photocatalysis. (a) Hydrogen evolution from water; (b) photochemical activation of $\mathrm{O}_{2}$; (c) photocatalytic oxidation or degradation of organic substrates [16].

used for the production of renewable, nonpolluting fuels and organic chemicals. So far, the catalysts for photocatalytic reactions are mainly semiconductors and transition metal complexes. However, these materials suffer from many disadvantages, such as low conversion efficiency, low selectivity of products, and poor stability.

Graphitic carbon nitrides $\left(\mathrm{g}-\mathrm{C}_{3} \mathrm{~N}_{4}\right)$ are polymer semiconductor materials with a two dimensional graphene layered structure. Owning to their more stable structure and better photocatalytic performance compared with traditional polymer semiconductors, they have good potential in the utilization of solar energy as a unique metal-free semiconductor photocatalyst. Wang et al. [81] prepared carbon nitride $\left(\mathrm{g}-\mathrm{C}_{3} \mathrm{~N}_{4}\right)$ with a conjugated polymer-graphite phase by using heat-induced self-polymerization of cyanamid. A recent breakthrough was achieved by using this material for water splitting into hydrogen under visible light in the absence of a metal, opening a new pathway for the study of photocatalytic materials. The g- $\mathrm{C}_{3} \mathrm{~N}_{4}$ material has an appropriate bandgap of $2.7 \mathrm{eV}$, corresponding to an optical wavelength of $460 \mathrm{~nm}$. Both the HOMO and the LUMO are compatible with the oxidation and reduction potential of water, that is, the electron vacancy ("hole") in the HOMO is sufficiently reactive and can oxidize water to oxygen, while the electron in the LUMO has enough reduction potential to reduce water to hydrogen [82] (Fig. 8). To further solve the problems in the photocatalytic process of low quantum efficiency, frequent photogenerated carrier recombination and too large bandgap $(\lambda<460 \mathrm{~nm})$ with a low utilization of solar energy, extensive research efforts have been devoted to the modification of $\mathrm{g}-\mathrm{C}_{3} \mathrm{~N}_{4}$ to improve the chemical composition, bandgap structure, optical absorption properties and electronic transport properties. These methods include copolymerization modification, mesoporous modification, synthesis pathway improvement and co-catalyst modification, and have resulted in significant improvements in the photocatalytic decomposition of water into hydrogen [83].

In addition, the bottom of the conduction band of $\mathrm{g}-\mathrm{C}_{3} \mathrm{~N}_{4}$ is $1.3 \mathrm{~V}$, which allows the activation of molecular oxygen to superoxide radicals. Meanwhile the top of the valance band is
$1.4 \mathrm{~V}$, which means that with $\mathrm{g}-\mathrm{C}_{3} \mathrm{~N}_{4}$, water or hydroxyl cannot be directly oxidized to a free hydroxyl radical. Therefore, g- $\mathrm{C}_{3} \mathrm{~N}_{4}$ can be applied in the selective synthesis of the organic photocatalyst by using molecular oxygen as the oxidant, involving alkane oxidation, alcohols oxidation and olefins oxidation [82]. Taking oxidation dehydrogenation of benzyl alcohol to benzaldehyde as an example, $\mathrm{g}-\mathrm{C}_{3} \mathrm{~N}_{4}$ gave more than $99 \%$ selectivity and $57 \%$ conversion under visible light irradiation for $3 \mathrm{~h}$ at $100{ }^{\circ} \mathrm{C}$ (Table 2). As compared with the traditional catalysts, this green organic selective oxidation route has several advantages, including mild reaction conditions, visible light source and molecular oxygen oxidant, and in addition a reaction system with neither metal, strong acid nor strong alkali.

Besides the applications of $\mathrm{g}-\mathrm{C}_{3} \mathrm{~N}_{4}$ in photocatalysis, composite materials composed of nanocarbon and other metal-free catalysts can also provide new routes for photocatalysis. Recently, Baeg et al. [84] reported the synthesis of a novel graphene-based visible light-active photocatalyst which improved the efficiency of artificial photosynthesis systems. By adding porphyrin enzymes, the graphene catalyzed the production of formic acid from $\mathrm{CO}_{2}$ and sunlight. The product can be used for the chemicals and fuel cell in the plastics industry. This graphene-based visible light-active photocatalyst exhibited a higher catalytic activity and much higher overall efficiency than other catalysts. It also had good electron transport capability and the larger surface area of graphene which can contribute to speeding up the chemical reactions.

\section{Macro-shaping of nanocarbon materials}

The large scale application of nanoscopic carbon materials with a loose powder structure as the catalyst or catalyst support is hampered because of the large pressure drop across the catalyst bed and the problems of mass and heat transfer in industrial fixed bed reactors. Therefore, the macroscopic shaping of nanocarbon materials is one of the key issues for the large scale applications of these metal-free catalysts. Practical

Table 2

Selective oxidation of alcohols [82].

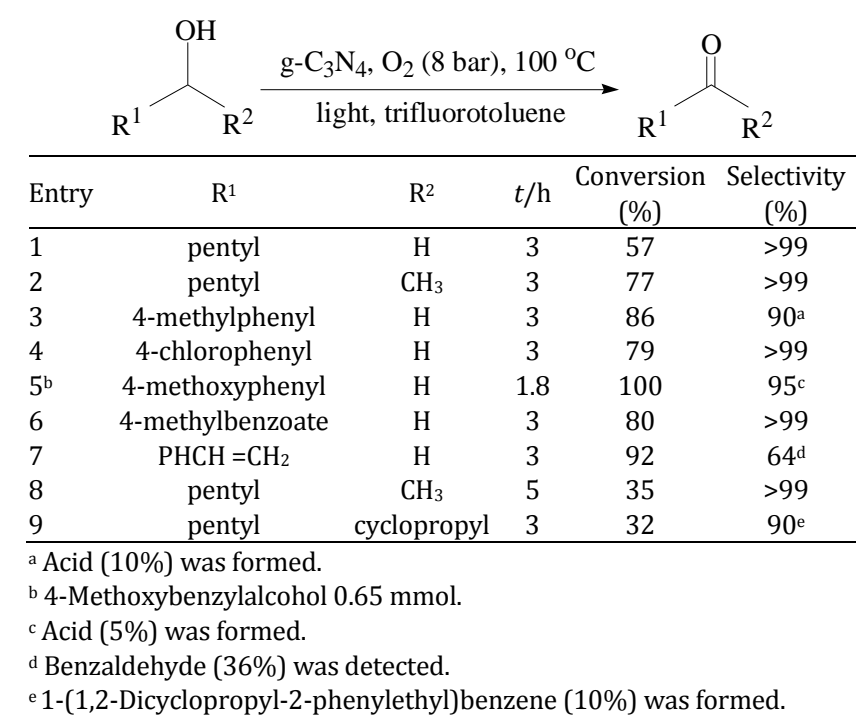


nanocarbon catalysts should possess sufficient mechanical strength, an open macroscopic structure and long term stability. To get such a macroscopic nanocarbon structure, one method is the immobilization of nanocarbon onto other porous materials with a well defined shape and mechanical strength. These materials used as catalyst showed a similar or even better catalytic performance to commercial powder carbon materials. The macroscopic nanocarbon supports include foam metals, natural minerals, porous carbon and ceramics, which are usually in situ synthesized by chemical vapor deposition of the active metal onto a porous support. Jarrah et al. [85] successfully immobilized carbon nanofibers on a porous nickel support. The surface area of the Ni-CNFs-foam composite was increased with the loading of the CNFs from less than 1 to 30 $\mathrm{m}^{2} / \mathrm{g}$ and had a pore volume of $1 \mathrm{~cm}^{3} / \mathrm{g}$. Su et al. [86,87] reported that Basalt lava erupted from Mount Etna containing iron oxide particles can be used as catalysts and supports to synthesize and immobilize carbon nanotubes and nanofibers. The composites obtained were highly active and stable catalysts for the oxidative dehydrogenation of ethylbenzene to styrene. García-Bordejé et al. [88] used a $\gamma$-alumina wash-coating layer impregnated with a nickel salt to cover the walls of a macroporous ordierite ceramic monolith. The composite of ceramic monoliths and carbon nanofibres (CNFs) with the average diameters of $5-30 \mathrm{~nm}$ was prepared by the catalytic growth of CNFs. Vanhaecke et al. [89] realized the catalytic growth of carbon fiber array on a SiC substrate in a floating ferrocene and toluene solution. This material was used as a micro-reactor that was efficiently employed in a diesel particulate filter as well as in heterogeneous catalysis. Dai et al. [90] used dopamine or dopamine polymer as the carbon source and silica spheres as template to make a polymer/silica nanocomposite that then was carbonized in nitrogen to synthesize hollow carbon spheres and "yolk-shell' structured carbon nanocomposite. Recently, our research group [91] reported an ion exchanged resin method in solid process at relatively low temperatures $\left(400-800{ }^{\circ} \mathrm{C}\right.$ ) to prepare carbon nanotube spheres with a mm-scale and highly graphitized structure (Fig. 9). This method processes the advantages of low cost, easy operation and low energy consumption. The resulting CNT spheres exhibited excellent catalytic activity and higher selectivity for styrene in ethylbenzene oxidative dehydrogenation reactions than commercial carbon nanotube powders. Chizari et al. [92] recently successfully prepared macroscopic shaped $\mathrm{N}$-doped carbon nanotubes (N-CNTs) on SiC foam. This N-CNTs/SiC composite showed a higher desulfurization performance compared with an unsupported N-CNTs for hydrogen sulfide oxidation, and also exhibited high stability during the test at high space velocity.

\section{Conclusion and outlook}

Metals and metal oxides have been widely used as catalysts in various industrial processes. Nanocarbon materials as a novel inorganic metal-free catalyst have the following unique advantages compared with the metal catalyst: (1) Nanocarbons are composed of nanographite-structure unit cells, and have good electrical conductivity and ability to store/release electrons. They have high specific surface areas and pore volumes and large amounts of surface defects. Heteroatoms (N, O, P...) are bonded or doped to the defects in carbon materials to form a variety of surface functional groups. (2) Nanocarbon materials can be widely used in a variety of catalytic processes, and have excellent catalytic properties in some typical reactions. For example, in the oxidative dehydrogenation of alkanes, they enabled the reaction to be performed with a high activity at a lower temperature, as well as with no coke formation. Nanocarbon used as the electrocatalyst in ORR showed comparable activity and stability to the commercial Pt-based catalyst, while they have low cost and high corrosion resistance. (3) Owing to their wide availability, environmental friendliness and no heavy metal pollution, carbon catalysts are candidates for green chemistry with low emission and an efficient use of the chemical feedstock.

There are still many key issues and challenges that need to be solved in nanocarbon metal-free catalysis: (1) The use of nanocarbon materials in gas phase reactions is mainly limited to the oxidative dehydrogenation of alkanes. Their applications in new reaction systems are urgently required. Although various carbon materials have exhibited excellent catalytic performance, there is still a long way before their commercialization. Nitrogen or boron-doped nanocarbons are promising carbon materials. However, it is still very challenging to determine the exact location of the nitrogen atoms in the nanocarbon structure, the chemical nature of the active sites, and the doping mechanism. Carbon nitrides and doped nanocarbon composites have been shown to be a new route for the development of carbon materials. (2) Many fundamental aspects including the nature of the active sites, reaction mechanism and the exact role of the interface in catalytic process are still not clear. A reliable qualitative and quantitative identification method is needed to identify the structure and properties of the surface defects and functional groups. The contribution of metal impurities in a trace amount to the catalytic activity is still a matter of conversy. Therefore, in situ characterization techniques under complex conditions need to be developed to monitor the catalytic reaction process. By the synthesis and control of model carbon materials to give a clean surface and specific functional groups, they can be combined with reaction kinetics and theoretical calculations to probe the nature of the carbon catalysis. (3) For industrial applications, it is essential to develop simple and highly efficient approaches for the large scale production of carbon nanomaterials with a defined structure and surface chemistry. Some progress have been made so far, but nevertheless, various reaction parameters still need to be explored and optimized for the large scale conditions, improvement of the product purity and yield and reducing the cost. Although the large scale application of nanocarbon metal-free catalysts is still far away, the development of new materials and the understanding of the structure, nature and application of carbon materials have become deeper. Therefore, nanocarbon catalysts will undoubtedly receive more extensive attention in the field of material science and chemical catalysis. 

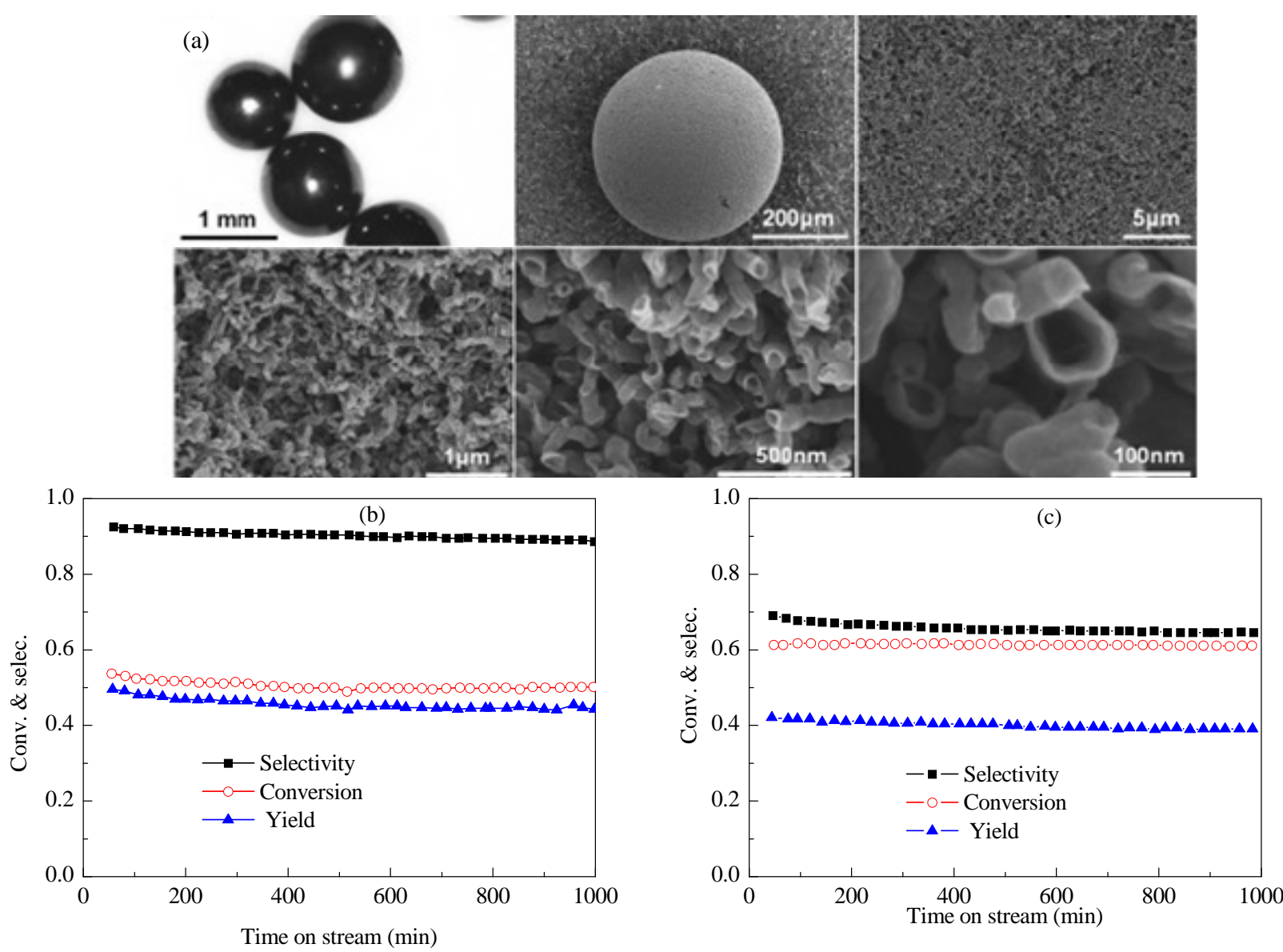

Fig. 9. Microscopic images of purified CNT spheres calcined at $800{ }^{\circ} \mathrm{C}(\mathrm{a})$, time-on-stream profiles of ethylbenzene conversion, styrene selectivity and yield over CNT spheres (b) and over CNT powdes (c) [91].

\section{References}

[1] Jiang H F, Wang Y G, Liu H L, Liu P. Chin J Org Chem (江焕峰, 王玉 刚, 刘海灵, 刘鹏. 有机化学), 2004, 24: 1513

[2] Yang G, Ma Y, Xu J.J Am Chem Soc, 2004, 126: 10542

[3] Chen D J, Wang Y T, Klankermayer J. Angew Chem, Int Ed, 2010, 49: 9475

[4] Su D S, Zhang J, Frank B, Thomas A, Wang X C, Paraknowitsch J, Schlögl R. ChemSusChem, 2010, 3:169

[5] Figueiredo J L, Pereira M F R. Catal Today, 2010, 150: 2

[6] Mestl G, Maksimova N I, Keller N, Roddatis V V, Schlögl R. Angew Chem, Int Ed, 2001, 40: 2066

[7] Keller N, Maksimova N I, Roddatis V V, Schur M, Mestl G, Butenko Y V, Kuznetsov V L, Schlögl R. Angew Chem, Int Ed, 2002, 41: 1885

[8] Zhao T J, Sun W Z, Gu X Y, Rönning M, Chen D, Dai Y C, Yuan W K, Holmen A. Appl Catal A, 2007, 323: 135

[9] Delgado J J, Su D S, Rebmann G, Keller N, Gajovic A, Schlögl R. J Catal, 2006, 244: 126

[10] Li P, Li T, Zhou J H, Sui Z J, Dai Y C, Yuan W K, Chen D. Microporous Mesoporous Mater, 2006, 95: 1

[11] Delgado J J, Chen X W, Su D S, Hamid S B A, Schlögl R. J Nanosci Nanotech, 2007, 7: 3495

[12] Su D S, Maksimova N, Delgado J J, Keller N, Mestl G, Ledoux M J, Schlögl R. Catal Today, 2005, 102-103: 110

[13] Yu D S, Nagelli E, Du F, Dai L M. J Phys Chem Lett, 2010, 1: 2165

[14] Frank B, Rinaldi A, Blume R, Schlögl R, Su D S. Chem Mater, 2010,
22: 4462

[15] Zhang J, Liu X, Blume R, Zhang A H, Schlögl R, Su D S. Science, 2008, 322: 73

[16] Frank B, Zhang J, Blume R, Schlögl R, Su D S. Angew Chem, Int Ed, 2009, 48: 6913

[17] Pereira M F R, Órfão J J M, Figueiredo J L. Appl Catal A, 1999, 184: 153

[18] Maciá-Agulló J A, Cazorla-Amorós D, Linares-Solano A, Wild U, Su D S, Schlögl R. Catal Today, 2005, 102-103: 248

[19] Zhang J, Su D S, Zhang A H, Wang D, Schlögl R, Hébert C. Angew Chem, Int Ed, 2007, 46: 7319

[20] Macia-Agullo J A, Cazorla-Amoros D, Linares-Solano A, Wild U, Su D S, Schlögl R. 1st International Symposium on Carbon for Catalysis (Carbo-Cat-1). Switzerland: Elsevier, 2004. 248

[21] Silva I F, Vital J, Ramos A M, Valente H, do Rego A M B, Reis M J. Carbon, 1998, 36: 1159

[22] Liu X, Su D S, Schlögl R. Carbon, 2008, 46: 547

[23] Frank B, Morassutto M, Schomacker R, Schlögl R, Su D S. ChemCatChem, 2010, 2: 644

[24] Muradov N. Catal Commun, 2001, 2: 89

[25] Muradov N, Smith F, T-Raissi A. Catal Today, 2005, 102: 225

[26] Huang L P, Santiso E E, Nardelli M B, Gubbins K E. J Chem Phys, 2008, 128: 7

[27] Lee S Y, Kwak J H, Han G Y, Lee T J, Yoon K J. Carbon, 2008, 46: 342

[28] Xie H, Wu Z L, Overbury S H, Liang C D, Schwartz V. J Catal, 2009, 267: 158

[29] Zhang J, Su D S, Blume R, Schlögl R, Wang R, Yang X G, Gajovic A. 


\section{Graphical Abstract}

Chin. J. Catal., 2013, 34: 508-523 doi: 10.1016/S1872-2067(11)60515-9

\section{Research progress in metal-free carbon-based catalysts}

SUN Xiaoyan, WANG Rui, SU Dangsheng* Institute of Metal Research, Chinese Academy of Sciences; National Institute of Clean-and-Low-Carbon Energy

This review highlights recent progress in the development of metal-free carbon-based catalysts, including understanding their surface properties, catalytic performance, reaction mechanism, and macroscopic architecture. The state-of-the-art and future challenges of metal-free heterogeneous catalysis are also discussed.

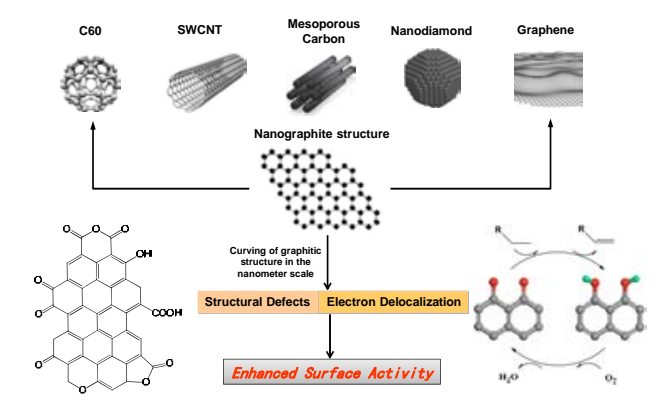

Angew Chem, Int Ed, 2010, 49: 8640

[30] Liu X, Frank B, Zhang W, Cotter T P, Schlögl R, Su D S. Angew Chem, Int $E d, 2011,50: 3318$

[31] Frank B, Blume R, Rinaldi A, Trunschke A, Schlögl R. Angew Chem Int Ed, 2011, 50: 10226

[32] Besson M, Blackburn A, Gallezot P, Kozynchenko 0, Pigamo A, Tennison S. Top Catal, 2000, 13: 253

[33] Kuang Y B, Islam N M, Nabae Y, Hayakawa T, Kakimoto M. Angew Chem, Int Ed, 2010, 49: 436

[34] Kang Z H, Wang E B, Mao B D, Su Z M, Gao L, Niu L, Shan H Y, Xu L. Appl Catal A, 2006, 299: 212

[35] Begin D, Ulrich G, Amadou J, Su D S, Pham-Huu C, Ziessel R. J Mol Catal A, 2009, 302: 119

[36] Hara M, Yoshida T, Takagaki A, Takata T, Kondo J N, Hayashi S, Dome K. Angew Chem, Int Ed, 2004, 43: 2955

[37] Peng F, Zhang L, Wang H J, Lü P, Yu H. Carbon, 2005, 43: 2397

[38] Yu H, Jin Y G, Li Z L, Peng F, Wang H J.J Solid State Chem, 2008, 181: 432

[39] Yu H, Peng F, Tan J, Hu X W, Wang H J, Yang J, Zheng W X. Angew Chem, Int Ed, 2011, 50: 3978

[40] Yang S X, Li X, Zhu W P, Wang J B, Descorme C. Carbon, 2008, 46: 445

[41] Aguilar C, Garcia R, Soto-Garrido G, Arriagada R. Appl Catal B, 2003, 46: 229

[42] Gao Y J, Ma D, Wang C L, Guan J, Bao X H. Chem Commun, 2011, 47 : 2432

[43] Wang X Q, Liu R, Waje M M, Chen Z W, Yan Y S, Bozhilov K N, Feng P Y. Chem Mater, 2007, 19: 2395

[44] Villa A, Tessonnier J P, Majoulet O, Su D S, Schlögl R. Chem Commun, 2009: 4405

[45] Yuan X L. [PhD Dissertation]. Changchun: Jilin Univ (袁晓玲. [博士 学位论文]. 长春: 吉林大学), 2012

[46] Yuan X L, Zhang M, Chen X D, An N H, Liu G, Liu Y, Zhang W X, Yan W F, Jia M J. Appl Catal A, 2012, 439-440: 149

[47] Kan-nari N, Okamura S, Fujita S, Ozaki J, Arai M. Adv Synth Catal, 2010, 352: 1476

[48] Dreyer D R, Jia H P, Todd A D, Geng J X, Bielawski C W. Org Biomol Chem, 2011, 9: 7292

[49] Jia H P, Dreyer D R, Bielawski C W. Tetrahedron, 2011, 67: 4431

[50] Kumar A V, Rao K R. Tetrahedron Lett, 2011, 52: 5188

[51] Verma S, Mungse H P, Kumar N, Choudhary S, Jain S L, Sain B, Khatri O P. Chem Commun, 2011, 47: 12673

[52] Chauhan S M S, Mishra S. Molecules, 2011, 16: 7256
[53] Dreyer D R, Jarvis K A, Ferreira P J, Bielawski C W. Polym Chem, 2012, 3: 757

[54] Dreyer D R, Bielawski C W. Chem Sci, 2011, 2: 1233

[55] Dreyer D R, Jia H P, Bielawski C W. Angew Chem, Int Ed, 2010, 49: 6813

[56] Su C L, Acik M, Takai K, Lu J, Hao S J, Zheng Y, Wu P P, Bao Q L, Enoki T, Chabal Y J, Loh K P. Nature Commun, 2012, 3: 1298

[57] Goettmann F, Fischer A, Antonietti M, Thomas A. Angew Chem, Int Ed, 2006, 45: 4467

[58] Goettmann F, Fischer A, Antonietti M, Thomas A. Chem Commun, 2006: 4530

[59] Goettmann F, Fischer A, Antonietti M, Thomas A. New J Chem, 2007, 31: 1455

[60] Su F Z, Antoniettia M, Wang X C. Catal Sci Technol, 2012, 2: 1005

[61] Wang Y, Wang X C, Antonietti M. Angew Chem, Int Ed, 2012, 51: 68

[62] Wang Y, Zhang J S, Wang X C, Antonietti M, Li H R. Angew Chem, Int Ed, 2010, 49: 3356

[63] Wang Y, Li H R, Yao J, Wang X C, Antonietti M. Chem Sci, 2011, 2: 446

[64] Shao Y, Sui J, Yin G, Gao Y. Appl Catal B, 2008, 79: 89

[65] Gong K P, Du F, Xia Z H, Durstock M, Dai L M. Science, 2009, 323: 760

[66] Ewels C P, Glerup M J, Nanosci J. Nanotechnol, 2005, 5: 1345

[67] Tang Y, Allen B L, Kauffman D R, Star A. J Am Chem Soc, 2009, 131: 13200

[68] Biddinger E J, von Deak D, Ozkan U S. Top Catal, 2009, 52: 1566

[69] Matter P H, Ozkan U S. Catal Lett, 2006, 109: 115

[70] Liu R L,Wu D Q Feng X L, Müllen K. Angew Chem, Int Ed, 2010, 49: 2565

[71] Dai L M, Chang D W, Baek J B, Lu W. Small, 2012, 8: 1130

[72] Wang H, Cote R, Faubert G, Guay D, Dodelet J P. J Phys Chem B, 1999, 103: 2042

[73] Matter P H, Zhang L, Ozkan U S. J Catal, 2006, 239: 83

[74] Matter P H, Ozkan U S. Catal Lett, 2006, 109: 115

[75] Qu L, Liu Y, Baek J B, Dai L. ACS Nano, 2010, 4: 1321

[76] Strelko V V, Kartel N T, Dukhno I N, Kuts V S, Clarkson R B, Odintsov B M. Surf Sci, 2004, 548: 281

[77] Stohr B, Boehm H P, Schlögl R. Carbon, 1991, 29: 707

[78] Jarrah N A, Li F, Ommen J, Lefferts L. J Mater Chem, 2005, 15: 1946

[79] Yang S B, Feng X L, Wang X C, Mullen K. Angew Chem, Int Ed, 2011, 50: 5339

[80] Ozaki J, Tanifuji S, Furuichi A, Yabutsuka K. Electrochim Acta, 2010, 55: 1864 
[81] Wang X C, Maeda K, Thomas A, Takanabe K, Xin G, Carlsson J M, Domen K, Antonietti M. Nat Mater, 2009, 8: 76

[82] Wang Y, Wang X C, Antonietti M. Angew Chem, Int Ed, 2012, 51: 68

[83] Zhang J S, Chen X F, Takanabe K, Maeda K, Domen K, Epping J D, Fu X Z, Antonietti M, Wang X C. Angew Chem, Int Ed, 2010, 49: 441

[84] Yadav R K, Baeg J O, Oh G H, Park N J, Kong K J, Kim J, Hwang D W, Biswas S K. J Am Chem Soc, 2012, 134: 11455

[85] Jarrah N A, Li F, Ommen J, Lefferts L.J Mater Chem, 2005, 15: 1946

[86] Su D S, Chen X W, Liu X, Delgado J J, Schlögl R. Adv Mater, 2008, 20: 3597

[87] Rinaldi A, Zhang J, Mizera J, Girgsdies F, Wang N, Hamid S, Schlögl
R, Su D S. Chem Commun, 2008: 6528

[88] García-Bordejé E, Kvande I, Chen D, Rönning M. Carbon, 2007, 45: 1828

[89] Vanhaecke E, Ivanova S, Deneuve A, Ersen O, Edouard D, Wine G, Nguyen P, Pham C, Pham-Huu C. J Mater Chem, 2008, 18: 4654

[90] Liu R, Mahurin S M, Li C, Unocic R R, Idrobo J C, Gao H J, Pennycook S J, Dai S. Angew Chem, Int Ed, 2011, 50: 6799

[91] Zhang J, Wang R, Liu E Z, Gao X F, Sun Z H, Xiao F S, Frank G, Su D S. Angew Chem, Int Ed, 2012, 51: 7581

[92] Chizari K, Deneuve A, Ersen O, Florea I, Liu Y, Edouard D, Janowska I, Begin D, Pham-Huu C. ChemSusChem, 2012, 5: 102

\title{
纳米碳材料非金属催化的研究进展
}

\author{
孙晓岩 ${ }^{\mathrm{a}}$, 王 锐 ${ }^{\mathrm{a}, \mathrm{b}}$, 苏党生 ${ }^{\mathrm{a}, *}$ \\ a 中国科学院金属研究所沈阳材料科学国家(联合) 实验室, 辽宁沈阳 110016 \\ ${ }^{\mathrm{b}}$ 北京低碳清洁能源研究所, 北京102211
}

\begin{abstract}
摘要: 纳米碳材料直接作为催化剂的非金属碳催化是目前材料科学与催化领域的前沿方向之一. 相对于传统金属催化剂, 纳米 碳材料催化剂具有高效环保、低能耗、耐腐蚀等优点. 在烃类转化、化学品合成、能源催化等领域表现出优异的催化性能和发 展潜力. 综述了近年来纳米碳非金属催化研究的最新进展, 主要包括新型纳米碳材料的表面性质、催化特性、反应机理和宏观制 备等关键问题, 并对纳米碳催化存在的挑战和前景进行了展望.
\end{abstract}

关键词: 纳米碳材料; 非金属; 多相催化

收稿日期: 2012-11-10. 接受日期: 2013-01-06. 出版日期: 2013-03-20.

*通讯联系人. 电话: (024)83970029; 传真: (024)83970019; 电子信箱: dssu@imr.ac.cn

基金来源：国家自然科学基金(21133010，21103203，50921004); 国家重大科学问题导向项目(973计划, 2011CBA00504); 中组部 千人计划海外人才引进项目.

本文的英文电子版由Elsevier出版社在ScienceDirect上出版(http://www.sciencedirect.com/science/journal/18722067).

\section{1. 前言}

非金属催化剂作为新兴的绿色催化剂体系在近年 来受到广泛关注. 这是由于与传统的金属催化剂相比, 非金属催化在许多工业催化过程中具有更加高效、环保 和经济等优点. 其中有机非金属催化剂种类众多, 如含 有 $\mathrm{N}, \mathrm{P}$ 富电子中心的小分子有机物、树状大分子、离子 液体等, 主要广泛应用于各类均相的有机化学反应, 如 重排反应、环加成、缩合、烷基化、羰基化等 ${ }^{[1 ~ 3]}$.

纳米碳材料是近年来发展起来的一类重要的无机 非金属催化剂, 纳米碳材料在烃类转化、精细化工、燃 料电池、太阳能转化等多个领域里表现出了优于传统金 属催化剂的性能, 具有巨大的发展潜力, 逐渐成为非金 属催化领域的前沿方向之一[4,5]. 纳米碳非金属催化是 直接使用纳米碳材料自身作为催化剂, 并不负载或添加 任何金属, 活性中心为表面的缺陷结构或官能团. 相对 于金属催化剂, 纳米碳材料作为催化剂具备成本低廉、

无重金属污染、环境友好等优点, 在许多催化过程中表 现出选择性高、条件温和、长期稳定性好等优势. 本文 主要对纳米碳材料非金属催化剂在多相催化体系的催
化性能、反应机理和宏观制备等关键问题的研究进展加 以综述.

\section{2. 纳米碳材料的结构和表面化学性质}

许多应用于催化过程中的纳米碳材料通常具有基 本的石墨结构, 按照结构维度的不同, 既包括传统的活 性炭、炭黑和石墨, 也包括富勒烯、纳米管及纳米纤维、 石墨烯、多孔碳等新型纳米碳材料.

纳米碳材料可以通过弧光放电、氧化减薄、化学气 相沉积等剧烈过程而制得; 其石墨结构无法保持完整, 经过化学方法纯化处理后, 缺陷和边界位置的碳原子为 了实现自身价键的饱和, 这些结构缺陷将被修饰上杂原 子官能团, 进而具备一定的酸碱性质和氧化还原能力. 通常含氧或含氮官能团最为常见, 图1给出了纳米碳材 料表面存在的各种不同种类的含氧、氮官能团 ${ }^{[4]}$. 含氧 官能团由于在碳材料长期接触空气的过程中即可被氧 分子缓慢氧化而形成, 因而被广泛研究. 酸性氧官能团 包括羧酸、酸酐、内酯和酚; 羊基氧和醚类氧物种, 如 醌、吡喃酮、苯并吡喃, 通常被归属为碱性或中性氧官 能团. 


\section{3. 纳米碳材料的催化性能}

纳米碳材料本身具有的独特优势也决定了其具有 优异的催化性能. 首先, 纳米碳材料大多具有纳米尺度 的石墨结构, 具有一定的导电性和储存/释放电子能力, 可以促进催化反应关键基元步骤的电子转移效率, 进而 大大提高总包反应速率. 其次, 纳米碳材料一般具有较 高的比表面积和中孔体积, 表面活性位总数远高于常规 材料, 气体或液体分子可以在中孔内高效率扩散, 其催 化性能必然可以得到大幅度提高. 最后, 纳米尺寸的碳 材料表面的缺陷程度也高于常规材料, 丰富的缺陷位可 以容纳更多的含氧、氮等活性杂原子. 表1列出了可被纳 米碳材料催化的一些常见反应和所需的表面官能团或 活性位种类 ${ }^{[5]}$.

\section{1. 气相反应研究}

以往纳米碳催化气相反应的研究主要集中在氧化 脱氢体系. 2001年, Schlögl研究小组使用纳米碳纤维作 为催化剂实现了乙苯氧化脱氢 ${ }^{[6.7]}$; 发现反应温度为 547 ${ }^{\circ} \mathrm{C}$ 时, 纳米碳纤维的催化活性高于高分散的石墨, 稳定 性远远优于无定形的传统炭黑. 随后的一系列研究表 明, 多种结构的纳米碳材料均体现较好的催化性能, 其 活性接近甚至优于传统的氧化铁催化剂(图2 $)^{[8 \sim 13]}$. 这是 由于纳米碳材料表面的缺陷结构能够针定官能团作为 反应活性位, 同时石墨结构能够紧密固定这些活性物种, 使纳米碳材料在氧化气氛中仍能保持很好的热稳定 性 ${ }^{[14]}$. 2008年, 苏党生研究组 ${ }^{[15]}$ 首次实现纳米碳管催化 丁烷制丁烯和丁二烯, 经过微量P元素掺杂的纳米碳管 对应的工艺反应温度比现有工业催化过程降低了 100 $200{ }^{\circ} \mathrm{C}$. 纳米碳材料的表面氧物种分为亲核氧和亲 电氧两种, 亲核氧吸附缺电子的烷烃反应物分子, 并催 化氧化脱氢反应生成烯烃; 亲电氧吸附电子云密度高的 烯烃产物分子, 催化烯烃深度氧化为 $\mathrm{CO}$ 和 $\mathrm{CO}_{2}$, 导致催 化剂的选择性降低. 还有研究表明, 向石墨晶格结构中 引入微量氧化嗍, 可以修饰纳米碳表面的电子云分布, 抑制表面亲电氧物种的活性, 进一步提高烯烃产物的选 择性 ${ }^{[16]}$.

探讨碳催化材料的活性位本质也日益成为研究热 点之一. Pereira等 ${ }^{[17]}$ 将乙苯氧化脱氢活性与表面羰基、 苯醌含量进行了关联, 发现两者之间呈现线性关系. 动 力学研究表明, 活性碳上乙苯氧化脱氢过程可以用 Mars-van-Kreverlan型反应机理描述, 反应活性高低与表 面氧物种的氧化还原能力大小密切关联. 苏党生研究小 组 ${ }^{[18 ~ 20]}$ 通过研究乙苯脱氢和丁烷脱氢反应动力学, 并首
次尝试使用拟原位X射线光电子能谱对碳材料的表面活 性进行考察, 相继在反应机理和活性物种识别上取得突 破. 与多数金属和金属氧化物类似, 纳米碳催化过程遵 循双活性位的Langmuir-Hinshelwood反应机理, 烷烃活 化的活性物种应为类酮结构的 $\mathrm{C}=\mathrm{O}$ 氧物种 ${ }^{[19,20]}$. 研究认 为反应发生的机理是烷烃分子 $\mathrm{C}-\mathrm{H}$ 键先在类酮 $\mathrm{C}=\mathrm{O}$ 位 上进行脱氢反应, 同时类酮结构 $\mathrm{C}=\mathrm{O}$ 转变成羟基 $(\mathrm{C}-\mathrm{OH})$, 氧分子随后与脱下的氢原子反应生成产物水, $\mathrm{C}=\mathrm{O}$ 活性位得以循环, 如图3所示. 除乙苯氧化脱氢反应 之外, 该机理也被用于解释纳米碳纤维催化环己醇脱氢 制环己酩 ${ }^{[21]}, 1$-丁烯氧化脱氢制丁二烯 ${ }^{[22]}$, 丙烷氧化脱 氢制丙烯 ${ }^{[16]}$ 以及乙烷氧化脱氢制乙烯 ${ }^{[23]}$ 等过程.

表面缺陷位在纳米碳催化作用本质的研究中也占 据重要地位. Muradov ${ }^{[24]}$ 发现碳材料可以催化甲烷高温 裂解制氢反应. 包括活性炭、炭黑、石墨、C60、CNT、 金刚石等在内的 30 余种碳材料均具有催化活性, 其中炭 黑具有最好的比活性. 研究发现, 甲烷分解的反应活性 与碳材料结构的有序程度有明显的关联, 随着碳材料微 晶尺寸的减小, 无序度增加, 催化活性提高 ${ }^{[25]}$. 由此可 以推测甲烷分解的活性位为碳材料中的缺陷结构. 这一 结论最近由Huang等 ${ }^{[26]}$ 通过第一原理计算和Lee等 ${ }^{[27]}$ 通 过乙炔化学吸附实验所证明. Liang研究组 ${ }^{[28]}$ 在富勒烯 结构的石墨碳材料上的异丁烷氧化脱氢的研究结果表 明, 反应催化活性与表面含氧官能团的含量无明显关系, 而主要取决于富勒烯开笼的比例. 由于目前还无法有效 地直接识别和定量表面缺陷位的种类和数量, 因此大部 分碳催化气相反应的机理和活性位本质仍然存在争议.

最近, 在新型反应体系中取得的一些进展为拓展 非金属碳材料作为下一代新型催化剂提供了新的方向. 本课题组 ${ }^{[29]}$ 近期的研究工作表明, 纳米金刚石作为催 化剂在无氧和无水蒸气保护的较低温度下即可实现乙 苯直接脱氢制取苯乙烯(图4), 其催化活性为工业氧化 铁催化剂的3倍, 且反应过程中没有发生明显积碳,具有 较好的稳定性, 在乙苯脱氢工业领域具有良好的应用 前景. 研究表明, 纳米金刚石中的碳原子并非完全的 $s p^{3}$ 杂化，表面碳原子在较大的表面曲率作用下会发生 部分石墨化，同时表层石墨烯的结构缺陷被大量氧原 子饱和, 形成了独特的“金刚石-石墨烯”的核壳纳米结 构, 从而使纳米金刚石具有优异的催化性能. 随后在纳 米金刚石催化正丁烷氧化脱氢反应中发现, 纳米金刚 石表面容易发生相变而石墨化 ${ }^{[30]}$, 转变成一种外层为 包裹3 10层洋苟状的富勒烯层、内核为金刚石的核壳 
结构, 并诱发亲电氧物种的脱除和亲核氧物种的原位 生成, 从而促进烯烃的生成. 最近, Frank等 ${ }^{[31]}$ 考察了多 种碳材料在丙烯醛氧化制丙烯酸反应中的催化性能, 结果表明具有弯曲的石墨烯片层结构的碳材料, 如碳 纳米管、洋葱碳等具有较好的催化性能, 而主要为 $\mathrm{sp}^{3}$ 杂化的纳米金刚石则具有很低的丙烯酸选择性. 他们 将反应机理归结为氧分子解离吸附在(0001)面后形成 活泼的环氧官能团, 然后迁移到棱边缘位点. 丙烯醛分 子吸附在酮/醌类氧等亲核氧位, 使其被环氧物种氧化 生成丙烯酸(图5).

\section{2. 液相反应研究}

除气相脱氢反应之外, 纳米碳材料作为催化剂在液 相反应中的应用也日益受到关注. Besson等 ${ }^{[32]}$ 报道了活 化处理的酚醛树脂衍生的碳材料可以催化环己酮液相 氧化反应, 产物中已二酸的选择性可达 $33 \%$. 他们对碳 材料上含氧官能团与其环已酮氧化反应性能进行关联 时发现, 两者之间不存在明显的基团含量与活性之间的 线性关系, 这表明液相氧化反应过程远较气相的氧化脱 氢反应过程复杂. Kuang 等 ${ }^{[33]}$ 发现, 纳米碳材料可以直 接参与到醇类催化氧化的反应循环, 温和条件下即可在 硝酸介质中实现氧分子与醇的反应. 纳米碳管也可以催 化苯、甲苯、氯苯和硝基苯的 $\mathrm{H}_{2} \mathrm{O}_{2}$ 羟基化 ${ }^{[34]}$, 其氧活化 能力与碳管表面曲率有一定联系. 曲率与催化性能的相 关性在纳米碳管催化 9,10 -二氢葱液相氧化脱氢反应中 也有报道, 研究人员归结到 “屋顶”型的9,10-二氢葱分子 与纳米碳管之间有着更强的范德华作用 ${ }^{[35]}$. 从2004年 起, 彭峰课题组在酸修饰的碳材料催化酯化反应方面进

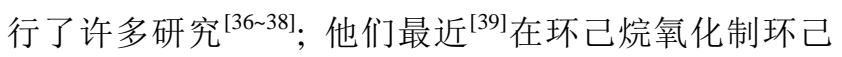
醇反应中发现, 碳纳米管的催化性能与其氧官能团含量 成反比, 这可能是由于官能团与缺陷的引入导致了电子 的定域作用, 而材料的长程有序度和电子离域作用才有 利于反应性能的提高. 纳米碳材料也可用于含酚废水的 湿空气氧化, 一般认为该过程涉及 $\mathrm{OH} \cdot$ 自由基链式机理 的亲电反应, 然而关于碳材料表面的活性中心及催化性 能的影响因素尚未有定论. Yang 等 ${ }^{[40]}$ 认为纳米碳管催 化苯酚氧化反应的主要活性中心是表面羧基; 而 Aguilar等 ${ }^{[41]}$ 认为碳材料催化含氮污染物氧化消除反应 的活性与其酸性基团无关, 反应的活性中心应为碱性的 类酮类苯醌基的结构. 马丁等 ${ }^{[42]}$ 报道了还原的氧化石 墨烯(RGO)能在室温条件下高效催化硝基苯加氢制取苯 胺, 认为还原后的石墨烯边缘缺陷有利于反应物分子的 活化.
通过对碳材料进行功能化可使其表面具有特定的 酸性或碱性, 从而成为固体酸或固体碱催化剂. Wang 等 ${ }^{[43]}$ 通过重氮苯磺酸来磺化多孔碳材料, 得到的固体酸 催化剂对酯化、缩合反应具有良好的催化性能. 氨基功 能化可使碳材料表面具有一定碱性. 据报道, 经氨基功 能化后的碳管作为具有活性的固体碱催化剂可高效催 化甘油三酸酯和甲醇的酯交换反应, 且催化剂易于循环 使用 ${ }^{[44]}$. 袁晓玲等 ${ }^{[45,46]}$ 通过乙二胺修饰多孔碳材料, 其 苯酚和草酸二甲酯酯交换合成草酸二苯酯和草酸苯甲 酯的催化性能明显优于负载型金属氧化物催化剂, 并且 催化剂通过处理后即可重复使用而催化性能基本不变. Kan-naril等 ${ }^{[47]}$ 报道了活性炭经过氨基功能化后, 催化 Knoevenagel缩合和酯交换反应具有较高的活性.

近年来, 氧化石墨烯由于特殊的物理化学性质(比 如强酸性、强氧化性), 在有机反应领域展现了巨大的应 用潜力, 比如硫化物的氧化 ${ }^{[48]}$ 、烯烃和其它碳氢化合物 的氧化 ${ }^{[49]} 、$ Friedel-Crafts反应 ${ }^{[50]}$ 、Aza-Michael加成 ${ }^{[51]}$ 、 缩合反应 ${ }^{[52]}$ 、开环聚合反应 ${ }^{[53]}$ 等. Bielawski研究组 ${ }^{[54]}$ 在氧化石墨烯领域进行了大量研究, 受到了广泛关注. 2010年, 他们首次报道了氧化石墨烯高效催化氧化/水合 反应, 催化醇类氧化制酮、醛, 烯氧化制二酮, 炔水合制 醛、酸和酮 ${ }^{[55]}$. 不过, 氧化石墨烯作为有机反应的催化 剂, 其主要缺点是催化剂用量过高(一般的氧化反应需 要60\% 400\%). Loh研究组 ${ }^{[56]}$ 最近发现, 简单的碱和酸 处理即可在氧化石墨烯表面产生大量缺陷、提高了反应 活性并降低了催化剂用量; 其在温和条件下催化胺氧化 制亚胺反应, 达到98\%收率仅需要5\%的催化剂用量.

介孔的石墨相氮化碳mpg- $\mathrm{C}_{3} \mathrm{~N}_{4}{ }^{[57 \sim 59]}$ 作为一种类石 墨材料也在某些液相有机反应中表现了良好的催化性 能, 如Friedel-Crafts酰基化反应、氧基和炔基化合物的环 化反应. 研究认为, mpg- $\mathrm{C}_{3} \mathrm{~N}_{4}$ 催化剂可以通过其氨基基 团形成氢键或者电子转移来活化反应物分子, 经过碱处 理的氮化碳可作为固体碱催化剂催化Knoevenagel缩合 和酯交换反应 ${ }^{[60]}$. 王心晨等 ${ }^{[61]}$ 的一系列研究发现, 使用 双氧水或者氧气做氧化剂,掺杂的mpg- $\mathrm{C}_{3} \mathrm{~N}_{4}$ 在液相氧化 反应中有非常优异的催化性能, 克服了传统氧化过程中 污染严重的问题, 同时具有高选择性、易与产物分离回 收等优势. 嗍和氟掺杂的 $\mathrm{C}_{3} \mathrm{~N}_{4}$ 可催化环己烷氧化制环己 酩 ${ }^{[62]}$; 硼和氟一定比例时, 催化剂的选择性甚至可高达 接近 $100 \%$ (转化率5.3\%). 嗍掺杂的 $\mathrm{C}_{3} \mathrm{~N}_{4}$ 可高选择性(接 近 $100 \%)$ 地催化甲苯、乙苯液相氧化制苯甲酫、苯乙酮 反应, 以及许多其它芳香烃的氧化反应 ${ }^{[63]}$. 


\section{3. 电化学氧还原反应研究}

氧还原反应(oxygen reduction reaction (ORR))的高 效催化剂长期以来都是优化燃料电池性能的关键. 虽然 贵金属铂基催化剂被视为最佳的燃料电池负极材料, 但 Pt电极存在稳定性不高、CO中毒、高成本和储量有限等 缺点, 导致燃料电池目前仍无法实现商业化应用. 为降 低和替代贵金属铂的使用, 人们对过渡金属族硫族化合 物、酶催化剂、含氮碳材料等替代催化剂进行了研究, 其 中原位掺杂的纳米碳管和介孔石墨阵列由于具有优异 的电催化活性、低成本、环境友好等优点, 被认为是很 有前景的非金属催化剂 ${ }^{[13,64,65]}$.

氮原子与碳原子具有相近的原子半径, 通过 5 个共 价电子与碳原子成键. 因此通过控制氮原子的掺杂量和 掺杂方法, 可以控制和改变碳材料的物理化学性质, 包 括电子特性、导电性、碱性、氧化性以及催化性能等 等 ${ }^{[64,66]}$. 氮掺杂方式有两种: 一种是原位掺杂, 将含氮 前驱体在碳材料合成过程中直接加入, 可使氮原子均匀 存在于整个碳材料基体中; 另一种是用含氮前驱体 $\left(\mathrm{NH}_{3}\right)$ 对碳材料进行后处理, 这种处理只是对碳材料表 面进行含氮基团功能化. 氮掺杂的碳材料通常是采用过 渡金属大环化合物的热解 ${ }^{[67]}$ 或者是金属盐与含氮前驱 体来合成 ${ }^{[68]}$. 不过即使通过极端的纯化方法, 也很难排 除极少量的金属杂质对氧还原反应性能的影响, 因此对 于金属是否在ORR催化机理中起作用一直存在争议. 2006年, 有学者 ${ }^{[69]}$ 通过乙腈在氧化铝 $\left(1 \times 10^{-6}\right.$ 以下金属污 染)上分解制备氮掺杂碳催化剂, 证实氮掺杂碳催化剂 的ORR活性并不需要金属的存在. Liu等 ${ }^{[70]}$ 报道了运用 非金属纳米浇铸方法合成的掺氮有序介孔石墨阵列 (NOMGAs), 其对ORR反应活性和稳定性远远高于商用 Pt-C催化剂, 他们将其归因于催化剂中氮原子的掺入. Gong等 ${ }^{[65]}$ (图6)通过化学气相沉积法合成了垂直生长的 掺氮纳米碳管阵列(VA-NCNTs), 作为燃料电池负极的 催化材料, 在碱性电解液中对四电子的ORR过程表现出 优异的电催化性能和稳定性, 同时高于商业的Pt基电极, 且不存在CO的毒化. 这主要由于氮原子在接受电子时 导致临近碳原子正电荷密度的增加. 该研究成果也为发 展可替代铂的非金属电催化材料提供了新的实验依据 和乐观前景.

目前发现至少存在三种不同的表面氮原子形态, 即 吡咯型、吡啶型和石墨型 ${ }^{[71}$ (图7), 但对于氮原子的本质 作用还没有一致的结论. 一般认为, 在石墨层边缘位上 的吡啶型氮原子对催化过程起活性作用 ${ }^{[72 ~ 74]}$. 最近有
研究表明, 石墨型的氮原子对ORR起活性非常重要 ${ }^{[70,75]}$. 此外, 也有学者提出氮原子仅仅是通过给出电子增加了 与氧原子的相互作用, 表面形成的阴离子自由基 $\mathrm{O}_{2}$-对 氮掺杂碳催化剂更有效 ${ }^{[76,77]}$.

与碳管结构相比, 石墨烯由于具有二维平面几何构 型的单原子薄片结构, 更有利于电子的传递, 因此也可 作为更有效的电极材料. 有研究表明, 具有相同氮含量 的掺氮石墨烯与掺氮的纳米碳管相比, 具有同样优异的 氧还原性能 ${ }^{[78]}$. 最近, Mullen研究组 ${ }^{[79]}$ 制备了一种石墨 烯基底的氮化碳纳米片(G-CN Nanosheets), 该材料具有 高氮量、薄片层厚度、高比表面积等优点, 在ORR反应 中表现出高电催化活性、长期稳定性和高选择性, 并且 优于无石墨烯存在的氮化碳纳米片以及商业的Pt-C催 化剂. 另外, 其它种类的碳材料在电催化中的应用也在 研究. Ozaki等 ${ }^{[80]}$ 最近报道了在 $0.5 \mathrm{~mol}$ 硫酸及在乙酰丙 酮化物和金属酞菁化合物存在下, 通过呋喃树脂碳化生 成的壳状纳米碳材料作为催化剂也具有较高的氧还原 反应性能.

\section{4. 光催化反应研究}

从太阳能中捕获能量直接转化成化学能, 用来生产 可再生、无污染的燃料或有机化学品, 是对环境影响最 小, 缓解能源危机最直接有效的方式. 目前光催化合成 催化剂主要使用的是金属半导体、过渡金属复合物等, 但仍存在太阳光利用率低、低产物选择性和稳定性不高 等缺点.

石墨相氮化碳 $\left(\mathrm{g}-\mathrm{C}_{3} \mathrm{~N}_{4}\right)$ 是具有类石墨烯结构的二维 片层状聚合物半导体材料, 与其他传统聚合物半导体相 比, 其结构和光催化性能非常稳定, 作为独特的非金属 半导体光催化剂在太阳能利用上展现出巨大的潜力. 王 心晨等 ${ }^{[11]}$ 利用氧胺热诱导自聚合反应合成了共轭聚合 物-石墨相氮化碳 $\left(\mathrm{g}-\mathrm{C}_{3} \mathrm{~N}_{4}\right)$, 并实现了无金属组分可见光 分解水制氢的突破, 开拓了光催化材料研究的新领域. 该材料禁带宽度为 $2.7 \mathrm{eV}$, 波长位于 $460 \mathrm{~nm}, \mathrm{HOMO}$ 轨道 的电子空穴水氧化产氧非常活泼, LUMO轨道的电子对 水还原产氢具有足够的还原势 ${ }^{[82]}$ (图8). 随后, 他们又针 对 $\mathrm{g}-\mathrm{C}_{3} \mathrm{~N}_{4}$ 在光催化过程中遇到的量子效率低, 光生载流 子复合严重, 禁带宽度偏大 $(\lambda<460 \mathrm{~nm})$, 不能有效利用太 阳光等问题; 利用共聚合改性、介孔化改性、合成线路 的改进和助催化剂对g- $\mathrm{C}_{3} \mathrm{~N}_{4}$ 的化学组成、能带结构、光 吸收性能和电子输运性能进行改性, 从而有效提高了光 催化分解水制氢的活性 ${ }^{[83]}$.

此外, g- $\mathrm{C}_{3} \mathrm{~N}_{4}$ 导带底的电极电位为 $1.3 \mathrm{~V}$, 能够有效 
活化分子氧产生超氧自由基, 而其价带顶的电极电位为 $1.4 \mathrm{~V}$, 不能直接氧化水或羟基生成羟基自由基. 因此, 还可适用于以分子氧为氧化剂的有机光催化的选择性 合成, 如烷烃氧化、醇类氧化、烯烃氧化 ${ }^{[82]}$. 以苯甲醇 氧化脱氢生成苯甲醛为例, 在 $100{ }^{\circ} \mathrm{C}$ 可见光照射反应 $3 \mathrm{~h}$, 转化率可以达到 $57 \%$, 选择性高于 $99 \%$ (表2). 与传统醇 类氧化催化剂相比, 该体系反应条件温和, 以可见光为 光源, 以分子氧为氧化剂, 不涉及任何金属, 更无强酸和 强碱, 是一种绿色的有机选择性氧化途径.

除了氮化碳在光催化领域的应用, 将碳材料与其他 非金属催化剂复合也是一条新的光催化剂路线. 最近, Baeg研究组 ${ }^{\left[{ }^{[4]}\right.}$ 报道了一种新型石墨烯基的高效光催化 剂可提高人工光合作用系统的效率. 他们使用石墨烯作 为光催化剂, 加以卟啉酶, 可以把太阳光和二氧化碳转 换成甲酸, 用于塑料行业的化学品和燃料电池的燃料. 测试结果表明, 基于石墨烯的光催化剂在可见光范畴下 功能强大, 其整体效益显著高于其他催化剂. 研究还发 现, 该材料具有良好的电子传输能力, 并且石墨烯较大 的比表面积有助于加快化学反应的转换过程.

\section{4. 纳米碳材料的宏观制备研究}

众所周知, 纳米碳材料通常具有松散结构的粉末, 由于在工业级的固定床反应器中使用时容易导致床层 产生很大压降和阻碍传质传热, 限制了其作为催化剂或 催化载体的大规模应用. 因此, 纳米碳材料成型也是非 金属催化规模应用的关键性难题之一. 实用纳米碳催化 材料必须具备足够的力学强度、敞开的宏观结构和长期 的稳定性. 将纳米碳固载在具有一定宏观结构和力学强 度的多孔载体上, 可获得宏观纳米碳结构, 这些材料作 为催化剂显示出了与商业化粉体碳材料相当甚至更优 的催化性能. 目前文献报道的纳米碳的宏观结构载体包 括: 泡沫金属, 天然矿石, 多孔碳, 陶瓷, 一般都是在多孔 载体上负载活性金属后在化学气相沉积条件下原位合 成纳米碳材料. Jarrah等 ${ }^{[85]}$ 在多孔镍载体上成功地固载 了碳纳米纤维, 该复合材料的比表面积随着碳纤维固载 的量增加而增加, 从 $1 \mathrm{~m}^{2} / \mathrm{g}$ 增加到 $30 \mathrm{~m}^{2} / \mathrm{g}$, 孔体积达 1 $\mathrm{cm}^{3} / \mathrm{g}$. 苏党生等 ${ }^{[86,87]}$ 用天然含铁的火山灰与膨润土作 为催化剂, 成功制备出碳纳米管和碳纳米纤维, 所得复 合材料可用于乙苯氧化脱氢反应制取苯乙烯. García-Bordejé等 ${ }^{[88]}$ 在包覆一层氧化铝的大孔堇青石陶 瓷上浸渍镍盐后, 催化生长碳纳米纤维, 实现了碳纳米 纤维和陶瓷的固载, 获得平均直径为 5 30 nm的碳纳米
纤维. Vanhaecke等 ${ }^{[89]}$ 用泡沫 $\mathrm{SiC}$ 作载体, 用二茂铁和甲 苯溶液浮动催化法生长阵列碳纤维材料, 进一步制备成 微反应器, 可用于柴油微粒的过滤及多相催化. Dai研究 组 ${ }^{[90]}$ 采用多巴胺或多巴胺聚合物作为碳源, $\mathrm{SiO}_{2}$ 作为模 板, 在惰性氮气中碳化制备了中空的纳米碳球和“蛋黄蛋壳“结构的纳米碳复合材料. 最近, 本课题组 ${ }^{[91]}$ 采用离 子交换树脂小球固相生长的方法成功制备了碳纳米管 小球(图9). 该方法在400 800 ${ }^{\circ} \mathrm{C}$ 的较低温度即可得到石 墨化程度良好、毫米尺度的纳米碳管小球, 具有成本低、 可控易行、能耗低的突出优点. 乙苯氧化脱氢反应结果 显示, 该碳管小球比商业碳管粉体具有更高的催化活性 和苯乙烯选择性. Chizari等 ${ }^{[92]}$ 最近成功制备了泡沫 $\mathrm{SiC}$ 固载的掺氮纳米碳管, 并发现该材料在硫化氢氧化反应 中与未固载的掺氮纳米碳管相比具有更高的脱硫性能, 能在高空速条件下保持长期稳定.

\section{5. 结论与展望}

金属和金属氧化物催化剂已被广泛地应用于化学 工业过程, 纳米碳材料作为一类新兴的无机非金属催化 剂, 相对于金属催化剂具有许多独特的优势. (1)许多纳 米碳材料具有纳米尺度的石墨结构, 具有一定的导电性 和储存/释放电子能力, 一般具有较高的比表面积和中孔 体积, 表面含有丰富的缺陷位, 可通过合适的杂环原子 (例如, 氮, 氧, 磷等) 掺杂和功能化来实现优化. (2)纳米 碳材料可广泛应用于多种催化过程, 并在某些典型反应 中具有优异的催化性能. 例如, 在烷烃氧化脱氢反应中, 在低温下就具有较高活性, 并且无积碳生成; 在电催化 氧还原反应中的活性与稳定性可謧美商业铂催化剂, 成本低, 耐腐蚀. (3)地球上的碳元素储量丰富, 利用过 程环保、无重金属污染, 符合绿色化学工业节能、减排 的高要求.

目前, 纳米碳材料非金属催化研究仍然存在许多 挑战和关键性问题亟待进一步解决: (1)纳米碳材料在 气相反应中的研究目前仍主要集中在烷烃氧化脱氢, 对于新型反应体系的拓展和应用还有待进一步发展, 多种碳材料虽然表现出优异的催化性能, 但仍与商业化 水平存在一定的差距. 发展氮或硼掺杂的碳纳米材料是 具有前景的方法, 但是确定杂原子在纳米碳结构中的位 置, 催化活性位的化学本质, 以及掺杂机制等问题仍然 是很大的挑战. 此外, 碳氮化合物和掺杂的复合纳米碳 材料也成为碳材料合成一条新的探索路线; (2)对纳米 碳催化过程中活性位本质、反应机理、界面作用等关键 
基础问题的认识还不清晰, 对于表面缺陷结构和官能团 的结构和性质还缺乏有效可靠的定性和定量识别, 某些 碳材料中存在的微量金属杂质是否对反应起催化作用 也存在争议, 因此需要进一步发展原位复杂条件下的表 征技术来监测本征催化反应过程, 合成并调控具有洁净 表面和含有特定官能团的模型碳材料, 并结合反应动力 学与理论计算等方法深入探究碳催化的作用本质; (3) 对于工业应用, 需要发展简单高效的方法去规模化生产
具有明确结构和表面化学性质的碳纳米材料, 目前虽然 已取得部分进展, 但仍然需要在宏量规模下对各项反 应参数进行探索优化, 提高产物的纯度和收率, 降低成 本及可操作性. 目前, 纳米碳材料非金属催化虽然离 规模化应用距离尚远, 但近年来随着各种新型碳材料 的开发以及对碳材料的结构、性质及其应用的认识逐 渐深入, 纳米碳催化研究必将在材料科学与催化化学 领域引起更加广泛的关注.

\title{
2nd International Congress on Catalysis for Biorefineries (CatBior 2013)
}

\author{
September 22-25, 2013, Dalian, China
}

http://catbior2013.dicp.ac.cn

\section{Call For Papers}

\section{Congress Introduction}

The Organizing Committee cordially invites you to participate in the 2nd International Congress on Catalysis for Biorefineries to be held in Dalian from 22nd to 25th September, 2013. The International Congress on Catalysis for Biorefineries originated in Torremolinos, Málaga, Spain in 2011. The congress alternates worldwide in odd years. This international congress aims to create a platform for the scientific exchange of the views and latest research findings in the development of clean and efficient processes for the catalytic conversion of biomass into fuels and chemicals.

\section{Scopes}

This congress is devoted to fundamental and applied research on catalytic processes for biomass transformation without enzymatic process. The topical areas of interest include, but are not limited to:

a) Catalytic transformation of cellulose, hemicelluose, lignin, and raw biomass.

b) Catalytic transformation of carbohydrates and sugar-derived products.

c) Catalytic transformation of oil, fats, algae and oleo-derived chemicals.

d) Thermochemical transformations of biomass and related catalytic upgrading technologies for bio-oil.

\section{Publications}

The most significant and original works will be selected for publication in the special issues of Catalysis Today (http:// www.journals.elsevier.com/catalysis-today/) and Chinese Journal of Catalysis (http://www.sciencedirect.com/science/ journal/18722067) after a peer-review process.

\section{Key Dates:}

- Online abstract submission: February 1st, 2013

- Deadline for submission of abstracts: April 1st, 2013

- Abstract acceptance notification: May 1st, 2013

- Deadline for early bird registration: July 1st, 2013

- Conference: September 22nd-25th, 2013

\section{Scientific Correspondence}

Professor Tao Zhang Chairman of the Organizing Committee

Director, Dalian Institute of Chemical Physics Chinese Academy of Sciences

457 Zhongshan Road, Dalian 116023, China

Tel: +86-411-84379015; Fax: +86-411-84691570

E-mail: taozhang@dicp.ac.cn

Website: http://catbior2013.dicp.ac.cn

Professor Aiqin Wang

Vice-chairman of the Organizing Committee

Dalian Institute of Chemical Physics

Chinese Academy of Sciences

457 Zhongshan Road, Dalian 116023, China

Tel: +86-411-84379348; Fax: +86-411-84375940

E-mail: aqwang@dicp.ac.cn

Conference General Contact:

Dr. Changzhi Li

Secretary of the Organizing Committee Dalian Institute of Chemical Physics

Chinese Academy of Sciences

457 Zhongshan Road, Dalian 116023, China

Tel: +86-411-84379738; Fax: +86-411-84375940

E-mail: catbior2013@dicp.ac.cn 